\title{
Changes in Cross-Section Geometry and Channel Volume in Two Reaches of the Kankakee River in Illinois, 1959-94
}

By PAUL J. TERRIO and JOHN E. NAZIMEK

U.S. GEOLOGICAL SURVEY

Water-Resources Investigations Report 96-4261

Prepared in cooperation with the

KANKAKEE COUNTY SOIL AND WATER CONSERVATION DISTRICT

Urbana, Illinois

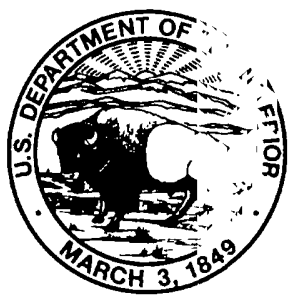




\section{U.S. DEPARTMENT OF THE INTERIOR \\ BRUCE BABBITT, Secretary}

U.S. GEOLOGICAL SURVEY

Gordon P. Eaton, Director

The use of firm, trade, and brand names in this report is for identification purposes only and does not constitute endorsement by the U.S. Geological Survey.

For additional information write to:

\section{District Chief}

U.S. Geological Survey

221 N. Broadway

Urbana, Illinois 61801
Copies of this report can be purchased from:

U.S. Geological Survey Branch of Information Services Box 25286

Denver, CO 80225 


\section{CONTENTS}

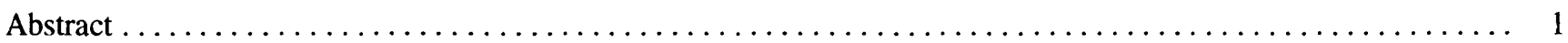

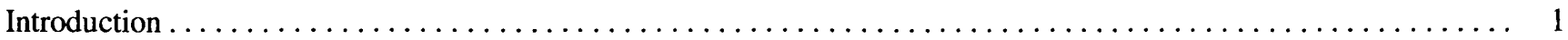

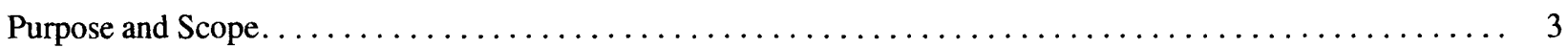

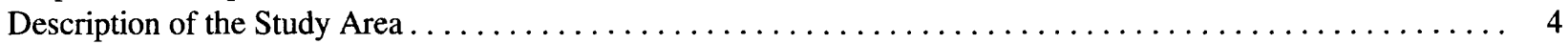

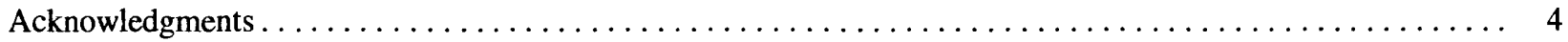

Compilation and Measurement of Channel Cross-Section Geometry Data $\ldots \ldots \ldots 6$

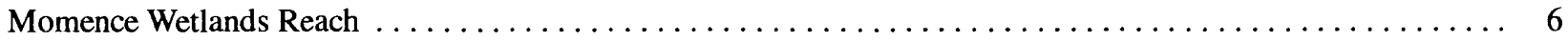

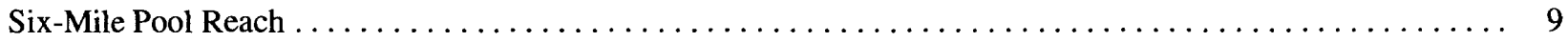

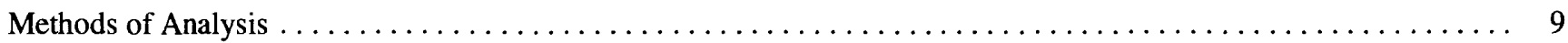

Changes in Cross-Section Geometry and Channel Volume $\ldots \ldots \ldots \ldots \ldots \ldots$

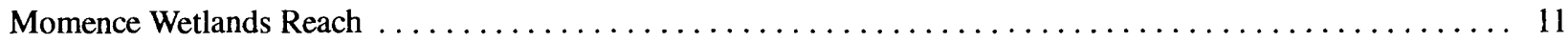

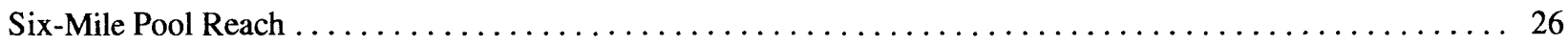

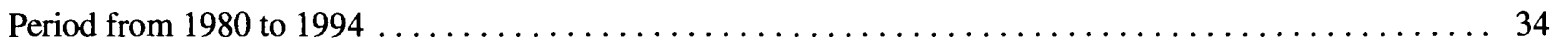

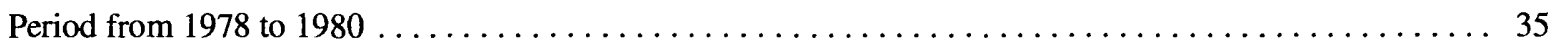

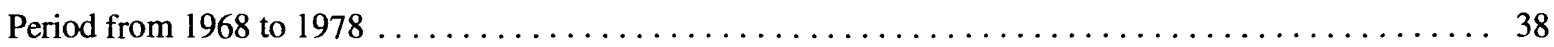

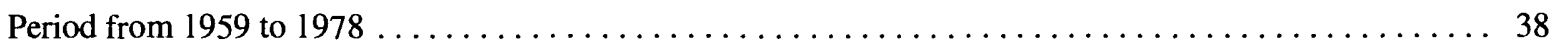

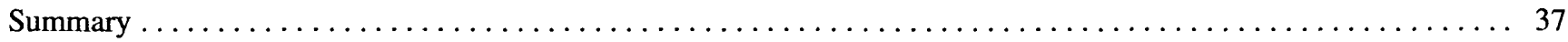

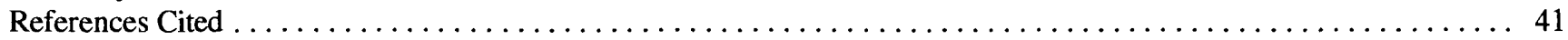

\section{FIGURES}

1. Map showing the Kankakee River Basin in Illinois and Indiana, the Momence Wetlands reach, and the

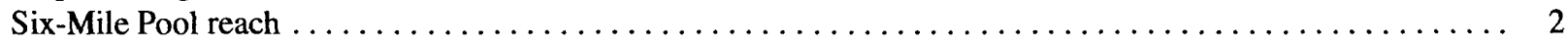

2. Graph showing annual peak streamflow at Kankakee River at Momence, Illinois, 1915-93 . . . . . . . . . 5

3-4. Maps showing:

3. Locations of the 35 cross sections in the Momence Wetlands reach of the Kankakee River in Illinois. . . . . 7

4. Water-surface elevations at the 35 cross-section locations in the Momence Wetlands reach of the

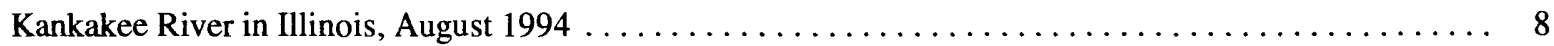

5. Locations of the 29 cross sections in the Six-Mile Pool reach of the Kankakee River in Illinois . . . . . . . 10

6-12. Graphs showing:

6. Schematic showing cross section and cross-section segment used to calculate cross-section segment

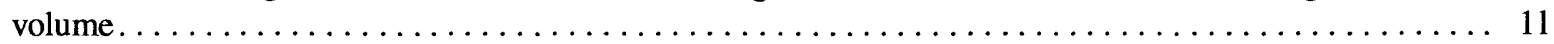

7. Cross-section geometry in 1980 and 1994 at the 35 cross sections in the Momence Wetlands reach of the Kankakee River in Illinois, view looking downstream. . . . . . . . . . . . . . . . . 15

8. Changes in channel volume of the 35 cross-section segments in the Momence Wetlands reach of the

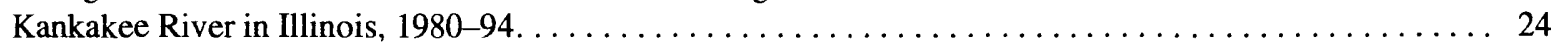

9. Cross-section geometry in 1959, 1968, 1978, 1980, and 1994 at the 29 cross sections in the Six-Mile Pool reach of the Kankakee River in Illinois, view looking downstream. . . . . . . . . . . . . . . 27

10. Changes in channel volume of the 29 cross-section segments in the Six-Mile Pool reach of the Kankakee River in Illinois, $1980-94$ and $1978-80 \ldots \ldots \ldots \ldots \ldots$

11. Changes in channel volume of eight cross-section segments in the Six-Mile Pool reach of the

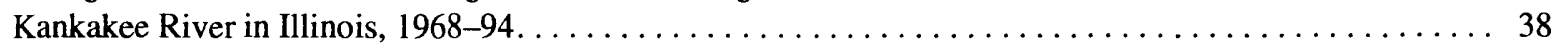

12. Changes in channel volume of four cross-section segments in the Six-Mile Pool reach of the Kankakee River in Illinois, 1959-94. 


\section{TABLES}

1. Cross-section areas and cross-section segment volumes in the Momence Wetlands reach of the Kankake? River in Illinois, 1980 and 1994

2. Cross-section areas in the Six-Mile Pool reach of the Kankakee River in Illinois, 1959-94

3. Cross-section segment volumes in the Six-Mile Pool reach of the Kankakee River in Illinois, 1959-94

4. Summary of changes in channel geometry and volume for the Momence Wetlands reach of the Kankakee River in Illinois, 1980-94.

5. Summary of changes in channel geometry and volume for the Six-Mile Pool reach of the Kankakee Rivor in Illinois, 1959-94.

\section{CONVERSION FACTORS AND VERTICAL DATUM}

\begin{tabular}{rll}
\hline Multiply & By & To obtain \\
\hline inch (in.) & 25.4 & millimeter \\
foot $(\mathrm{ft})$ & 0.3048 & meter \\
mile $(\mathrm{mi})$ & 1.609 & kilometer \\
square foot $\left(\mathrm{ft}^{2}\right)$ & 0.09290 & square meter \\
square mile $\left(\mathrm{mi}^{2}\right)$ & 2.590 & square kilometer \\
cubic foot per second $\left(\mathrm{ft}^{3} / \mathrm{s}\right)$ & 0.02832 & cubic meter per second \\
cubic yard $\left(\mathrm{yd}^{3}\right)$ & 0.7646 & cubic meter \\
ton & 907.1848 & kilogram \\
inch per mile $\left(\mathrm{in} / \mathrm{mi}^{3}\right)$ & 1.5786 & centimeter per kilometer \\
foot per mile $\left(\mathrm{ft} / \mathrm{mi}^{3}\right)$ & 0.1894 & meter per kilometer \\
pound per cubic foot $\left(\mathrm{lb} / \mathrm{ft}^{3}\right)$ & 16.01 & kilogram per cubic meter \\
pound per cubic yard $\left(\mathrm{lb} / \mathrm{yd}^{3}\right)$ & 0.5933 & kilogram per cubic meter \\
cubic yard per square mile per year $\left[\left(\mathrm{yd}^{3} / \mathrm{mi}^{2}\right) / \mathrm{yr}\right]$ & 0.2952 & cubic meter per square kilometer per year \\
ton per square mile per year $\left[\left(\mathrm{ton} / \mathrm{mi}^{2}\right) / \mathrm{yr}\right]$ & 350.2644 & kilogram per square kilometer pe* year \\
\hline
\end{tabular}

Sea level: In this report "sea level" refers to the National Geodetic Vertical Datum of 1929 (NGVD of 1929)-a geodetic datum derived from a general adjustment of the first-order level nets of both the United States and Canada, formerly called Sea Level Datum of 1929. 


\title{
Changes in Cross-Section Geometry and Channel Volume in Two Reaches of the Kankakee River in Illinois, 1959-94
}

\author{
By Paul J. Terrio and John E. Nazimek
}

\section{Abstract}

The upstream reaches of the Kankakee River in Indiana have been channelized, straightened, and ditched to facilitate agriculture; the downstream reaches of the river in Illinois have not been so altered. Concerns about the adjustments of this low-gradient river in response to these disturbances have led to studies of sedimentation along the Kankakee River in Illinois. The U.S. Geological Survey (USGS) began a study in 1992 to determine sedimentation characteristics of the Kankakee River in Illinois. As part of this study, changes in channel cross-section geometry and channel volume were determined by comparing measurements of cross-section geometry over time in two reaches of the Kankakee River. The study documents some of the adjustments of the Kankakee River to land-use changes and channelization in the upstream drainage area. The timing, magnitude, and process of adjustment are of interest in developing a better understanding of how alluvial stream systems in agricultural areas respond to disturbances in the drainage area. The data used for the study included cross-section measurements made by two State of Illinois agencies from 1959 to 1980 and measurements made by the USGS in 1994 .

The analyses indicated a net aggradation of about 133,600 cubic yards $\left(\mathrm{yd}^{3}\right)$ of sediment in the Momence Wetlands reach, a naturally meandering reach of the river, from 1980 to 1994. Aggradation occurred at 25 cross sections in this reach, and scour occurred at 10 cross sections. All but $\mathrm{c}$ ne of the cross sections in the upstream third of the reach indicated aggradation, whereas aggradation and scour were found in the middle and downstream thirds of the reach. The magnitude of change was greatest in the middle third of the reach and was least in the downstream third of the reach.

A net aggradation of approximately $298,600 \mathrm{yd}^{3}$ of sediment was indicated for the Six-Mile Pool, a pooled reach of the river upstream from a dam, from 1978 to 1994. Approximately $182,900 \mathrm{yd}^{3}$ of sediment accumulated from 1980 to 1994, and approximately $115,700 \mathrm{yd}^{3}$ of sediment accumulater from 1978 to 1980. Most of the aggradation occurred in the middle third of the Six-Mile Pool reach.

\section{INTRODUCTION}

The Kankakee River originates near South Bend, Ind., and joins the Des Plaines River near Wilmington, Ill., to form the Illinois River (fig. 1). The upper part of the river basin was historically a 3- to 5-mi wide wetland area through which the river channel meandered. This area was referred to as the Grand Marsh. The Grand Marsh extended from the headwaters of the Kankakee River in Indiana downstream to Momance, Ill. The river channel downstream from Momence had few meanders and was not bordered by wetlands (Bhowmik and others, 1980).

As the region was settled, parts of the Grand Marsh were converted to land suitable for agricultural use by constructing drainage ditches and channels. 


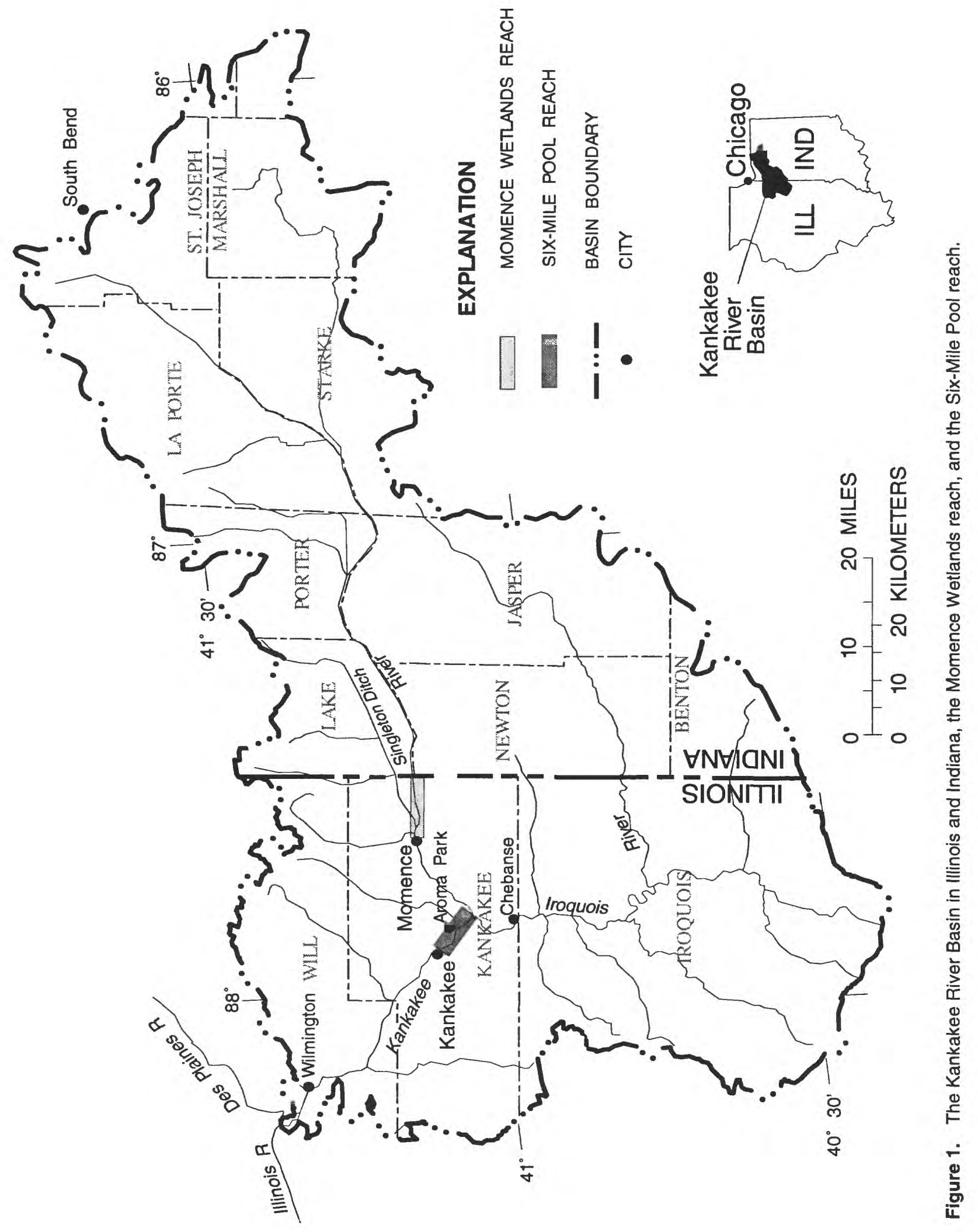


Around 1860, parts of the Kankakee River and tributary streams in Indiana were channelized and straightened to facilitate drainage of the surrounding areas and to decrease the extent and frequency of flooding of the former wetland areas (Houde and Klasey, 1968). By 1918, most of the Grand Marsh had been drained and converted to farmland, and the Kankakee River channel in Indiana had been completely channelized (U.S. House of Representatives, 1916 and 1931). The channelization of the Kankakee River reduced the length of the river in Indiana from about $240 \mathrm{mi}$ to about $90 \mathrm{mi}$ and increased the gradient of the river channel from less than $5 \mathrm{in} / \mathrm{mi}$ to about $12 \mathrm{in} / \mathrm{mi}$ (SEG Engineers and Consultants Inc., 1989). Disturbances of the river in Illinois were done around 1893 to reduce flooding and to facilitate drainage. These disturbances included widening and deepening the channel just upstream from Momence and removing part of a bedrock ledge at Momence (Bhowmik and others, 1980). Land use in the Kankakee River Basin in Illinois is predominantly agricultural and recreational associated with the river.

Sedimentation of the Kankakee River in Illinois has been a major concern to local residents and users of the river for many years. Concerns are that sand is being moved and deposited at faster than natural rates in the channel, and sedimentation is limiting the recreational, ecological, and overall usefulness of the river. The Illinois State Water Survey (ISWS) and the Illinois State Geological Survey (ISGS) investigated the Illinois part of the Kankakee River in the late 1970's and early 1980's (Bhowmik and others, 1980; Bhowmik and Bogner, 1981; Gross and Berg, 1981). These investigations indicated that the extensive drainage of the Grand Marsh and the channelization of the Kankakee River had caused increased sedimentation downstream from the State line. Based on information from aerial photographs and topographic maps, Gross and Berg (1981) concluded that the river had reached equilibrium by the early 1950 's; consequently, further increases in sedimentation rates in the Illinois part of the river should not be expected. Bhowmik and others (1980) expressed concern that the conclusions regarding sedimentation had been based on no more than 2 years of data. Ivens and others (1981) indicated that because of the short period of record, the equilibrium state interpreted from the data might represent only a temporary condition. Local residents and users of the river basin have continued to express concern that the rate of sedimentation has not reached equilibrium but has continued at an increased rate during the last few decades.

The results of the previous studies, the uncertainties in these results, and the continuing concern of local residents and users of the Kankakee River that aggradation of sediment is continuing, raise several questions. Is aggradation of sediment continuing in the Kankakee River in Illinois? Is sedimentation continuing at a constant rate? Are there spatial differences in sedimentation? Is sediment transported on a continual basis, does it fluctuate with streamflow in a predictable manner, or is it transported in slugs or sand bars as documented by Jacobson (1995) and Meade (1985)? Answering questions such as these will not only provide a better understanding of the Kankakee River system but also will provide information applicable to other disturbed rivers and contribute to the understanding of riverine responses to disturbances.

The U.S. Geological Survey (USGS), in cooperation with the Kankakee Soil and Water Conservation District, began a study in 1992 to determine sedimenttransport characteristics of the Kankakee River in Illinois based on three approaches. First, changes in sedimentation rates on the Kankakee River flood plain near the Illinois-Indiana State line were estimated utilizing dendrogeomorphic techniques. Second, channel crosssection geometry data from 1994 were compared with data from 1959, 1968, 1978, and 1980 to determine changes in channel geometry and volumetric capacity. Third, a mass balance of suspended-sediment transport will be computed from data collected at six suspendedsediment monitoring stations operated from 1993 through 1995.

This study documents the adjustments of the Kankakee River, a low-gradient river typical of many midwestern streams, to land-use changes and channelization. The timing, magnitude, and processes of adjustment are of interest in developing a better understanding of how disturbances are conveyed through alluvial stream systems and how the stream systems adjust to such disturbances.

\section{Purpose and Scope}

This report presents results of an analysis of changes in channel cross-section geometry and volume in two selected, distinctly different reaches of the Kankakee River in Illinois. Changes from 1980 to 1994 were evaluated for the reach of the Kankakee River, known as the Momence Wetlands (fig. 1). The 
Momence Wetlands extend from the Illinois-Indiana State line downstream to the mouth of Singleton Ditch near Momence, Ill. This reach of the river is typical of the naturally meandering river directly downstream from the extensively channelized reach in Indiana. Changes in channel geometry and volume among $1959,1968,1978,1980$, and 1994 were evaluated for the pooled reach of the Kankakee River known as the Six-Mile Pool. The Six-Mile Pool extends from the dam in Kankakee, Ill., upstream to near Aroma Park, Ill. This reach of the river is a permanently pooled section of the river channel, which traps many sediments that are transported through the upstream reaches.

\section{Description of the Study Area}

Two distinct reaches of the Kankakee River channel in Illinois were used for the analyses of changes in the cross-section geometry. The first reach (the Momence Wetlands reach) extends from the Illinois-Indiana State line downstream to the mouth of Singleton Ditch, upstream from Momence, Ill. (fig. 1). In this reach, the river channel meanders approximately $7.6 \mathrm{mi}$ through a largely undisturbed forested area. Many parts of the Momence Wetlands are frequently inundated by the Kankakee River. The area is characterized by the flood-plain type forest found along streams throughout the Midwest.

The river channel makes many turns and bends with various configurations through the Momence Wetlands. At normal streamflows, the channel ranges from 100 to $250 \mathrm{ft}$ wide with typically average depths ranging from 3 to $10 \mathrm{ft}$. In some places, particularly on the outside of bends, the river can be up to $15 \mathrm{ft}$ deep. Bed material in this reach of the channel is predominantly fine to medium sand, measuring 0.1 to $0.4 \mathrm{~mm}$ in diameter and has less than 5 percent silt and clay (Bhowmik and others, 1980).

Streambank materials are similar to bed materials, which are composed of primarily medium sand. Bhowmik and others (1980) analyzed streambank material along the Kankakee River in Indiana and found the material typically to contain less than 100 percent silt and clay. The cohesive characteristics of the streambank materials are not well documented. Bhowmik and others (1980) stated that "The banks of the river remained very stable." and "The river channel in Indiana is amazingly stable". However, others have stated that sedimentation problems in the Kankakee River "are primarily caused by unstable agricultural ditch banks and erosion of adjacent croplands" (SEG Engineers and Consultants, Inc., 1989).

The annual mean streamflow for the Kankakee River at Momence, Ill., for water years 1905-93 was $2,041 \mathrm{ft}^{3} / \mathrm{s}$, which represents an annual mean runoff of 12.1 in. over the entire drainage basin upstream from Momence. The drainage area at the downstream end of the Momence Wetlands reach is approximately $1,946 \mathrm{mi}^{2}$. Annual peak streamflows at Kankakee River at Momence, Ill., showed a generally increasing trend since the 1930's (fig. 2). The largest peak streamflow during the period of record at this location occurred in the spring of 1979.

The second reach of the river examined in this study, the Six-Mile Pool reach, extends from the mouth of the Iroquois River downstream to the dam in Kankakee, Ill. This reach is referred to as the Six-Mile Pool, although it is actually about 4.3-mi long (fig. 1). Land use along the Six-Mile Pool is predominantly agricultural with some residential and commercial use in the city of Kankakee, Ill., and near Aroma Park, Ill. Two long, sweeping bends in the river channel are present in this area. These bends are much more subtle than the meanders in the Momence Wetlands. Through the Six-Mile Pool, the river channel ranges from about 500 to $700 \mathrm{ft}$ in width and the average depth ranges from 10 to $15 \mathrm{ft}$ in most places. Islands and sand bars are present at various locations within the Six-Mile Pool. The size of bed material in the Six-Mile Pool is primarily fine to medium sand, but as much as 30 percent of the bed material can be composed of siltand clay-sized particles. No streamflow-gaging station is present at Kankakee, Ill.

Streamflows for the Six-Mile Pool can, however, be estimated by combining the streamflows measured at streamflow-gaging stations on the Kankakee River at Momence, Ill., and the Iroquois River near Chebanse, Ill. (fig. 1). The combined streamflow from these two streamflow-gaging stations was about $2,550 \mathrm{ft}^{3} / \mathrm{s}$ during the cross-section surveying in 1980 and about $1,207 \mathrm{ft}^{3} / \mathrm{s}$ during the surveying in 1994 . These values represent streamflows that are equalled or exceeded about 40 and 75 percent of the time, respectively. The drainage area at the downstream end of the Six-Mile Pool is approximately $2,159 \mathrm{mi}^{2}$.

\section{Acknowledgments}

The assistance of Roger Edmison and Gene Poehlman of the Illinois Department of Natural 


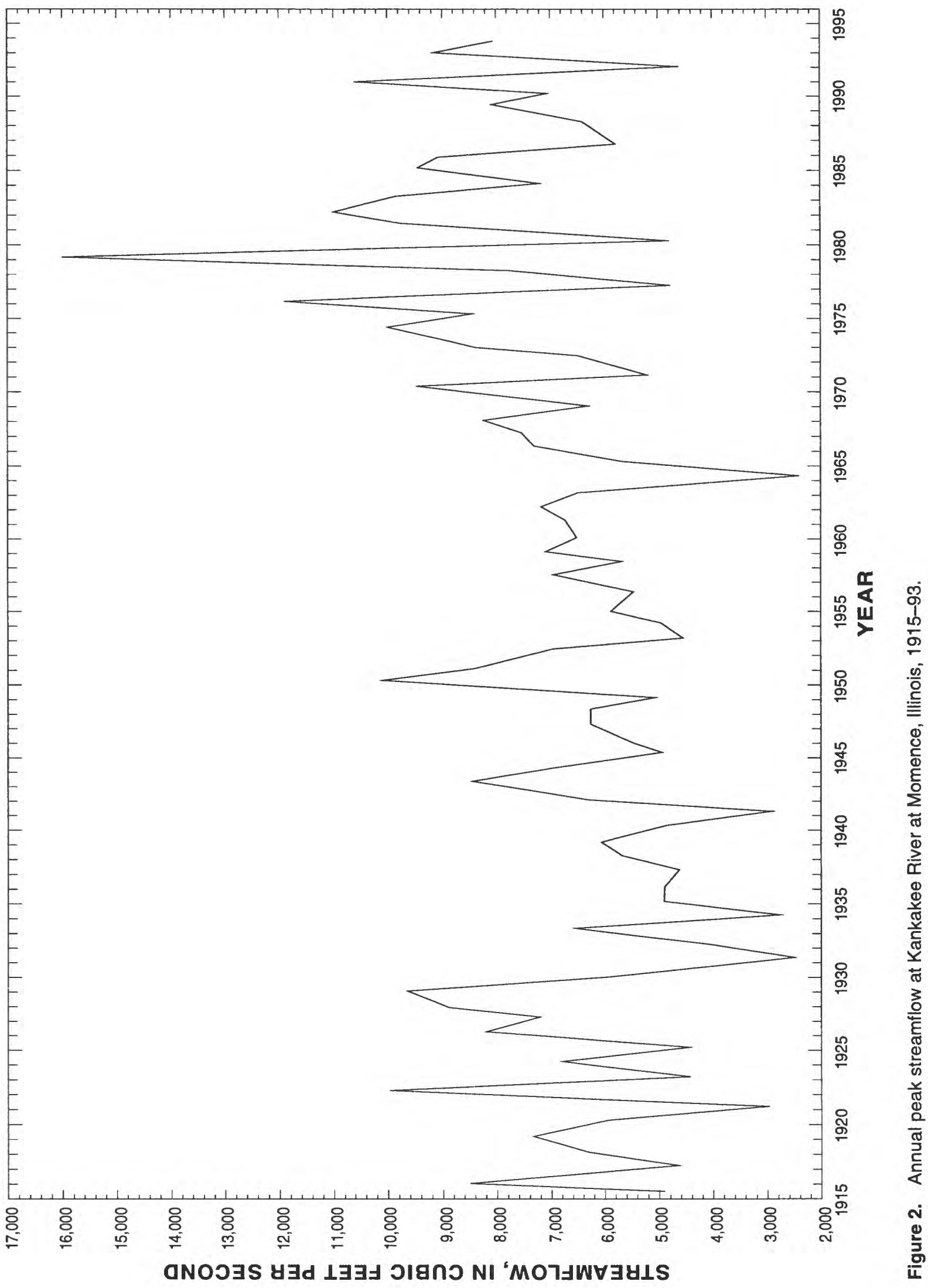


Resources, Office of Water Resources (IDNR/OWR, formerly the Illinois Department of Transportation, Division of Water Resources) for providing historical channel cross-section geometry data, associated documentation, and explanation is gratefully acknowledged. Field notes and explanations of channel cross section measured in 1980 by Bill Bogner of the ISWS also was vital to this study.

\section{COMPILATION AND MEASUREMENT OF CHANNEL CROSS-SECTION GEOMETRY DATA}

Historical cross-section geometry data for the Kankakee River channel in Illinois were available from previous measurements made by the IDNR/OWR and the ISWS. Cross-section measurements were made by the USGS in selected reaches of the Kankakee River in 1994 at locations where previous data had been collected.

\section{Momence Wetlands Reach}

The ISWS made cross-section geometry measurements at 35 locations on the Kankakee River in the Momence Wetlands reach in 1980 (fig. 3). Concrete posts with brass monuments were placed in the ground to mark the locations of the cross sections (Bhowmik and Bogner, 1981). The monument locations were recorded and referenced by surveying to trees, cabins, and other notable nearby landmarks. The elevations and locations of the monuments also were referenced to Illinois State Benchmark Stations. Survey notes documenting the locations of the monuments and reference points, and interpretive reports documenting the channel cross-section geometry in 1980 were obtained from the ISWS.

In August 1994, the USGS conducted a search for the monuments marking the 1980 cross-section locations. A global positioning system $\left(\mathrm{GPS}^{1}\right)$, metal detector, historical reports, and copies of the original survey field notes were used to locate the monuments, reference points, and landmarks. Only 16 of the 35 concrete monuments placed in 1980 were located in 1994. Two of the monuments found (cross sections 66 and

\footnotetext{
${ }^{1}$ The GPS used real-time, differentially corrected data to provide locations accurately within several meters.
}

68) had been disturbed and were not used for elevation references. The GPS, historical documentation, and survey notes were used to mark the probable former location of the monuments that were not located.

Cross-section measurements were made by the USGS in August and September 1994 at the 35 crosssection locations in the Momence Wetlands reach. The measurements were made with conventional surveying equipment, including a tag line, transit, and rod. Fourteen monuments were located in 1994 that did not have visible evidence of disturbance from their original location. The locations and elevations of these 14 monuments were assumed to be the same as when the monuments were placed in 1980. A temporary reference point was established and set to an arbitrary elevation of $50 \mathrm{ft}$ at cross sections where the original monuments were not located. Cross-section measurements were surveyed using these temporary datums at these locations. The temporary datums were later referenced to sea level by interpolating water-surface elevations between adjacent monumented cross sections. The water-surface profile during the cross-section measurements in 1994, the monuments that were located, and the monuments that were not located are shown in figure 4. All cross-section measurements were made perpendicular to the stream channel.

Additional measurements of cross-section geometry were made $20-50 \mathrm{ft}$ upstream, downstream, or both upstream and downstream from the primary cross section at five locations. These additional measurements were made to determine the consistency of the local channel geometry and to provide information on how well the measured cross section represented the local channel geometry. Some variations in geometry among the primary and additional cross sections were found. These differences were not large, however, and were between 0.02 and 10 percent of the primary crosssection area. In all cases, measurements indicated the same sedimentation process (aggradation or scour) from 1980 to 1994.

The stage of the Kankakee River was monitored at the USGS streamflow-gaging station at Momence, Ill., throughout the 5-day period when cross-section measurements were made in the Momence Wetlands reach in 1994 . The stage was practically steady, decreasing a total of only $0.06 \mathrm{ft}$ during the 5-day period, and streamflow ranged from 1,250 to $1,390 \mathrm{ft}^{3} / \mathrm{s}$. These streamflows are exceeded about 60-65 percent of the time, based on historical data. The total difference in water-surface elevation between the 

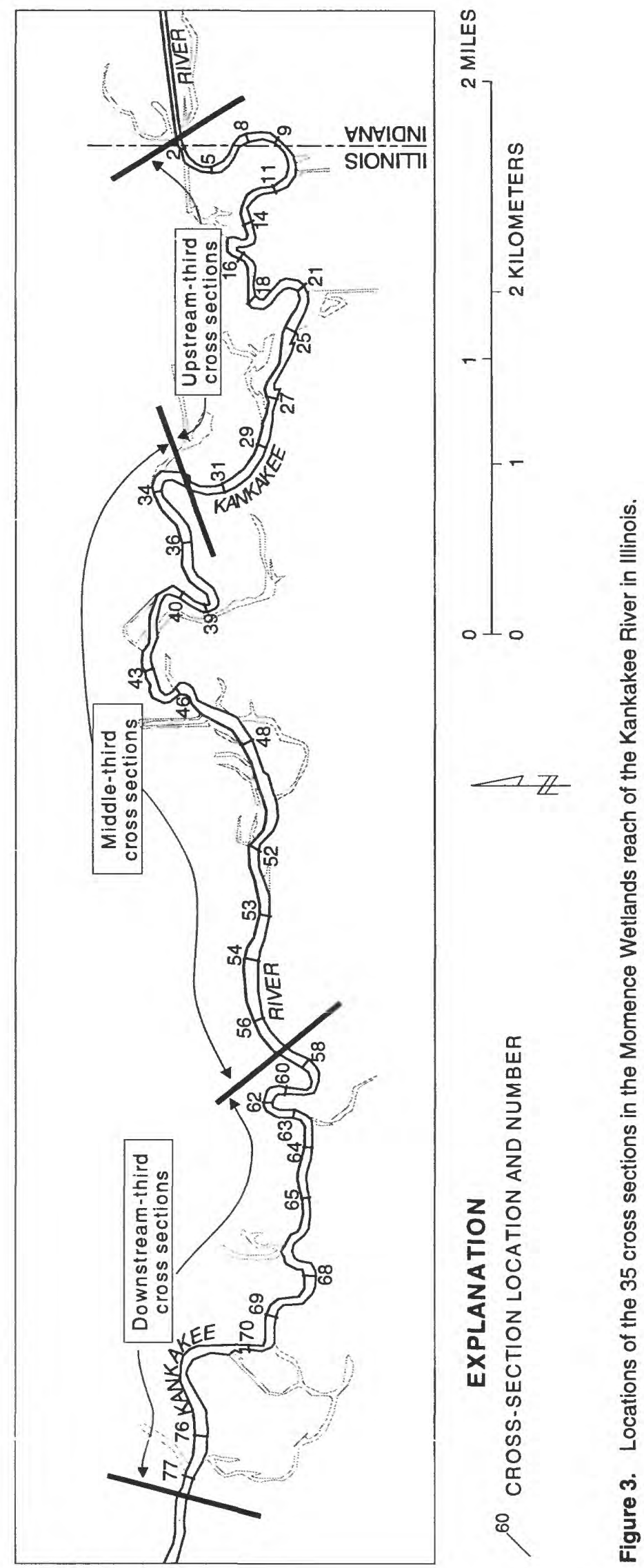


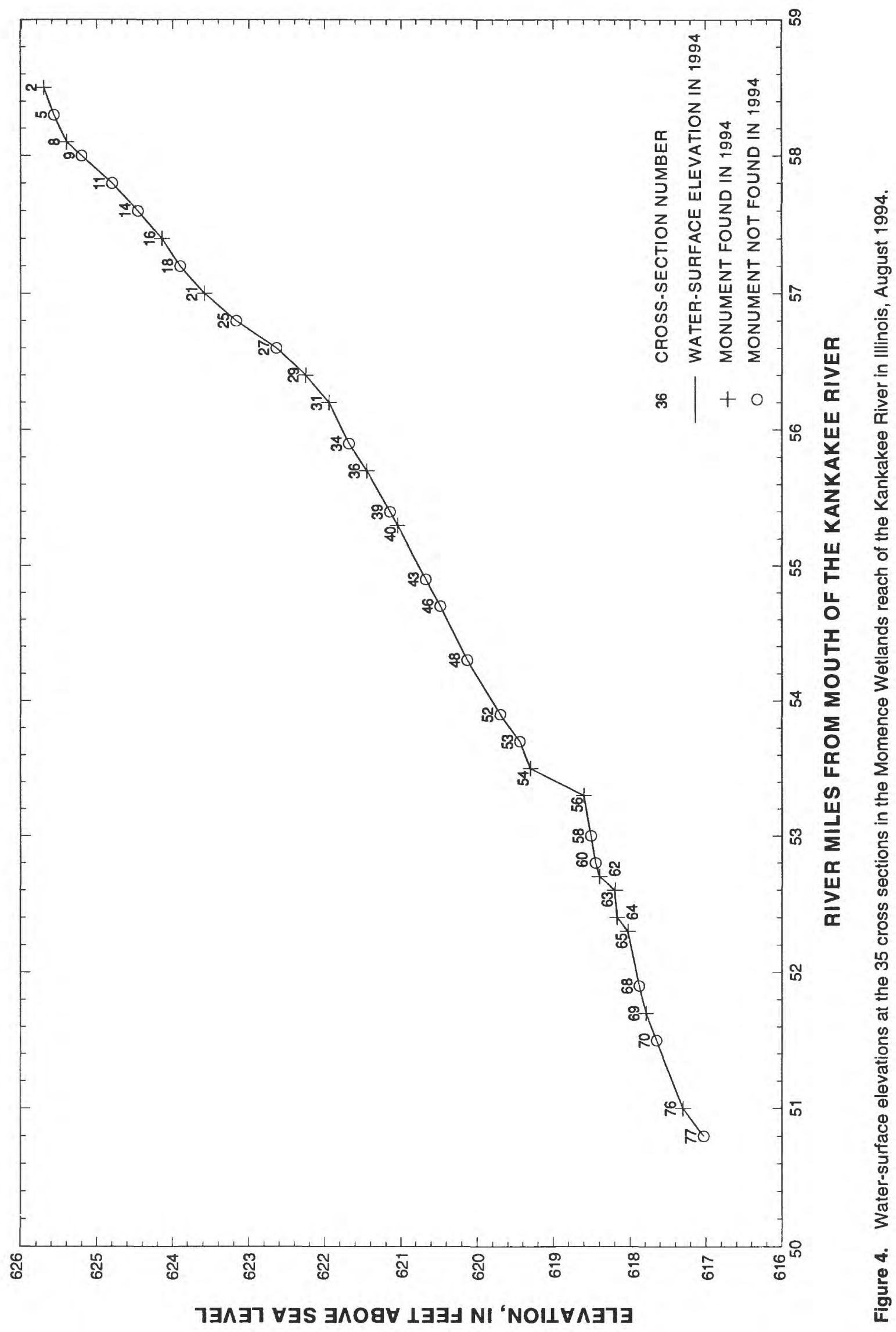


upstream most cross-section location and the downstream most cross-section location was $8.4 \mathrm{ft}$, which resulted in an average water-surface slope through the Momence Wetlands reach of $1.11 \mathrm{ft} / \mathrm{mi}$.

\section{Six-Mile Pool Reach}

Historical cross-section geometry data for the Six-Mile Pool reach included cross-section measurements made by the IDNR/OWR at 4 locations in 1959, 10 locations in 1968, and 32 locations in 1978. The ISWS made cross-section measurements in 1980 at all 32 locations measured by the IDNR/OWR in 1978. The cross-section locations were referenced to Illinois State Benchmark Stations with known horizontal locations and elevations. Survey notes, maps, interpretive reports documenting the locations of the cross sections, and the historical cross-section geometry were obtained from the IDNR/OWR and ISWS.

Cross-section geometry at 29 previous crosssection measurement locations in the Six-Mile Pool reach was measured by the USGS in September 1994 (fig. 5). Survey notes, maps, and reports were used to locate the previous cross-section locations. Cross-section geometry was measured utilizing a GPS and a digital Fathometer. The GPS was used to locate and record the horizontal position of the boat, while the Fathometer was used to simultaneously determine the depth of water. The Fathometer was not capable of accurately measuring depths of less than about $3 \mathrm{ft}$. No data were collected along the edges of the river or along the islands where the depth of water was less than $3 \mathrm{ft}$.

The stage of the Six-Mile Pool during the period when cross-section measurements were made in 1994 was determined from records provided by the Kankakee Metropolitan Wastewater Utility. These stages were referenced to the elevations of Illinois State Benchmark Stations. The stage of the Six-Mile Pool was stable during the 3-day survey period, and no substantial change in the streamflow of the Kankakee River at Momence, Ill., was observed during the 3-day period. The difference in water-surface elevation from the upstream end of the Six-Mile Pool near the mouth of the Iroquois River to the downstream end of the pool at the dam in Kankakee, Ill., (approximately $4.3 \mathrm{mi}$ ) was only $0.04 \mathrm{ft}$ on September 29, 1994 (the last day of the cross-section measurements). It is assumed that this difference in water-surface elevation represents the typically nominal difference between the upstream and downstream ends of the Six-Mile Pool during stable streamflow conditions.

\section{METHODS OF ANALYSIS}

This section describes the methods used to analyze the cross-section measurement data collected in 1959, 1968, 1978, 1980, and 1994 in the Momence Wetlands and Six-Mile Pool reaches of the Kankakee River. Initially, elevations of all cross-section measurements made in 1994 were referenced to sea level. This was done based on known elevations of State Plane Benchmarks and documented elevations of the concrete monuments placed in the Momence Wetlands in 1980. Elevations from previous cross-section measurements were determined from historical field notes and reports. The channel cross-section data were entered into a computer data base in flat-file format including the distance from the monument (or probable former monument location) and the elevation of the channel bottom.

The data were plotted with horizontal distance from the monument or edge of stream as the abscissa and with elevation as the ordinate. Plots of the crosssection measurements were digitized, and the crosssection area (area below the water surface) was measured in digitizer units and subsequently converted to square feet. The cross-section areas were determined to be below a specified water-surface elevation-the water-surface elevation during the cross-section measurement in 1980 in the Momence Wetlands reach and the water-surface elevation during the cross-section measurement in 1994 in the Six-Mile Pool reach.

Each cross-section measurement was used to represent the channel geometry for a segment of the channel extending one-half the distance upstream and downstream from the measured cross section to the next cross section (fig. 6). The segment of the river channel represented by each cross-section measurement is referred to as the cross-section segment. Lengths of the cross-section segments were determined as follows. The boundaries of the Six-Mile Pool and Momence Wetlands reaches were digitized from 7.5-minute USGS topographic quadrangle maps. The reach boundaries and the locations of the measured cross sections were then overlaid using a geographic information system. A line representing the center of the channel was digitized, and the distances between cross sections along this center line were calculated. These distances between cross sections were divided 


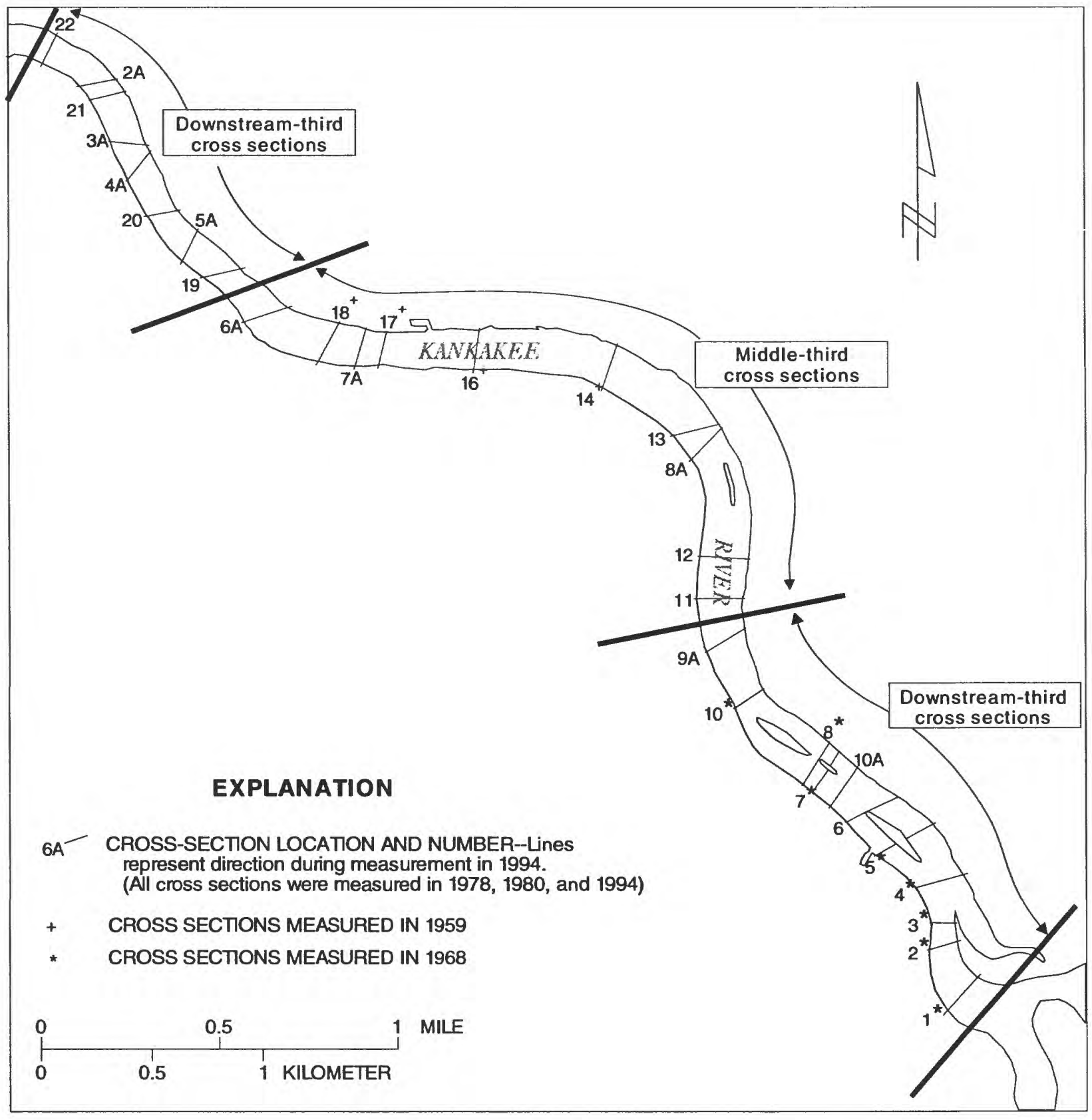

Figure 5. Locations of the 29 cross sections in the Six-Mile Pool reach of the Kankakee River in Illinois.

by two, and the resulting distance upstream and downstream was used as the cross-section segment length.

The volume of each cross-section segment was calculated as the cross-section area multiplied by the cross-section segment length. The river channel in the Momence Wetlands reach includes many side channels, oxbows, and interconnecting ditches. These features were not included in the calculation of channel volume. The cross-section areas and cross-section segment volumes for the Momence Wetlands and Six-Mile Pool reaches are given in tables 1-3.

\section{CHANGES IN CROSS-SECTION GEOMETRY AND CHANNEL VOLUME}

Changes in the cross-section geometry in the Momence Wetlands and Six-Mile Pool reaches of the Kankakee River were determined by comparing 


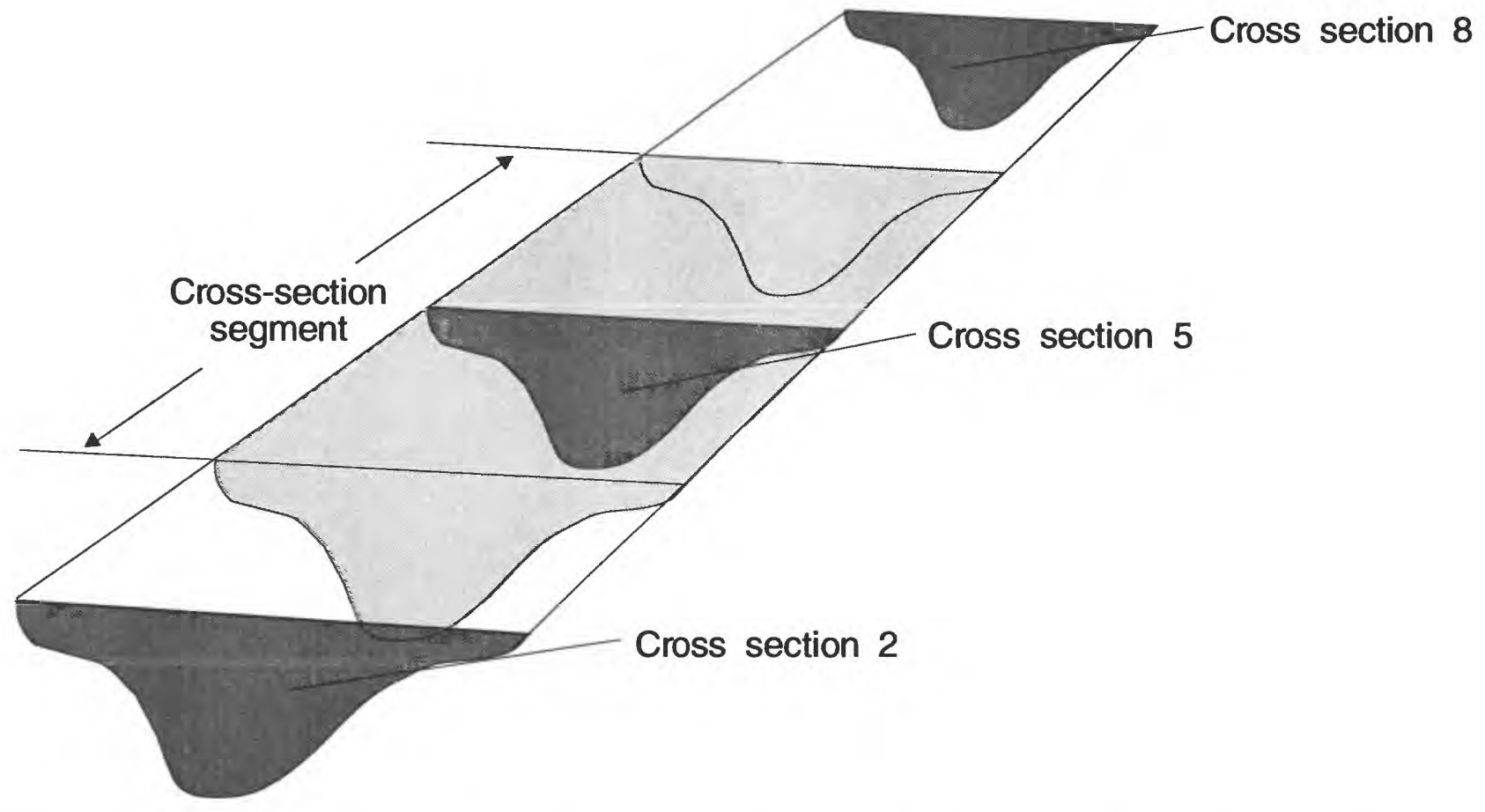

Figure 6. Schematic showing cross section and cross-section segment used to calculate cross-section segment volume.

historical and recent cross-section measurements. Comparisons were made by graphically plotting the cross-section geometry data from the historical and 1994 measurements, and evaluating changes in geometry, cross-section area, and channel volume. In this report, channel volume refers to the volume of the river channel below the water-surface elevation at the time cross-section measurements were made for the Momence Wetlands reach in 1980 and for the Six-Mile Pool reach in 1994.

\section{Momence Wetlands Reach}

The 1980 and 1994 cross-section measurements provide valuable information regarding the net change in channel geometry in the Momence Wetlands reach from 1980 to 1994. Comparison of cross-section measurements made in 1980 and 1994 indicates the net change in channel geometry between the two measurement times. The morphology of the Kankakee River channel in the Momence Wetlands undergoes continual change. Temporary conditions and changes during the intervening period are not known from these measurements. Regular and more frequent measurement of cross-section geometry would be needed to provide this information.
The locations of the 35 cross sections in the Momence Wetlands reach are shown in figure 3. Graphs of the cross-section geometry at the 35 locations measured in 1980 and 1994 are shown in figure 7. Each cross-section measurement was used to represent channel geometry for one-half of the distance between the cross section and the nearest cross section upstream and downstream (fig. 6). The net changes in channel volume from 1980 to 1994 in each of the cross-section segments in the Momence Wetlands reach are shown in figure 8.

Only 16 of the original concrete monuments placed in 1980 were located in 1994 (noted on figure 4). Cross-section measurements were made at probable locations of the original monuments determined from survey notes and records for cross sections where monuments were not located in 1994. Because of uncertainties in the exact locations of some of the 1980 cross-section locations, some crosssection plots from 1994 were matched by visual interpretation to cross-section plots from 1980 (fig. 4). Cross-section plots were adjusted horizontally for matching but not vertically, and the adjustments did not affect cross-section area or channel-volume calculations. For the purposes of calculating channel volume, it was assumed that the cross-section 
Table 1. Cross-section areas and cross-section segment volumes in the Momence Wetlands reach of the Kankakee River in Illinois, 1980 and 1994

[ft, feet; $\mathrm{ft}^{2}$, square feet; $\mathrm{yd}^{3}$, cubic yard]

\begin{tabular}{|c|c|c|c|c|c|}
\hline $\begin{array}{c}\text { Cross-section } \\
\text { number }\end{array}$ & $\begin{array}{l}\text { Cross-section } \\
\text { segment } \\
\text { length } \\
\text { (ft) }\end{array}$ & $\begin{array}{c}\text { Cross-section } \\
\text { area } \\
\text { in } 1980 \\
\left(\mathrm{ft}^{2}\right) \\
\end{array}$ & $\begin{array}{c}\text { Cross-section } \\
\text { area } \\
\text { in } 1994 \\
\left(\mathrm{ft}^{2}\right) \\
\end{array}$ & $\begin{array}{c}\text { Cross-section } \\
\text { segment } \\
\text { volume } \\
\text { in } 1980 \\
\left(y d^{3}\right)\end{array}$ & $\begin{array}{c}\text { Cross-section } \\
\text { segment } \\
\text { volume } \\
\text { in } 1994 \\
\left(y^{3}\right) \\
\end{array}$ \\
\hline 2 & 532 & 870 & 788 & 17,100 & 15,500 \\
\hline 5 & 877 & 850 & 727 & 27,600 & 23,600 \\
\hline 8 & 775 & 659 & 655 & 18,900 & 18,800 \\
\hline 9 & 912 & 608 & 667 & 20,500 & 22,500 \\
\hline 11 & 1,120 & 629 & 607 & 26,100 & 24,900 \\
\hline 14 & 1,070 & 608 & 520 & 24,100 & 20,600 \\
\hline 16 & 948 & 784 & 702 & 27,500 & 24,600 \\
\hline 18 & 1,040 & 875 & 732 & 33,700 & 28,200 \\
\hline 21 & 1,020 & 709 & 563 & 26,800 & 21,300 \\
\hline 25 & 1,150 & 921 & 757 & 39,200 & 32,200 \\
\hline 27 & 1,170 & 808 & 617 & 35,000 & 26,700 \\
\hline 29 & 1,050 & 770 & 718 & 29,900 & 27,900 \\
\hline 31 & 1,360 & 795 & 675 & 40,000 & 34,000 \\
\hline 34 & 1,370 & 634 & 688 & 32,200 & 34,900 \\
\hline 36 & 1,460 & 847 & 853 & 45,800 & 46,100 \\
\hline 39 & 1,020 & 988 & 891 & 37,300 & 33,700 \\
\hline 40 & 1,240 & 715 & 710 & 32,800 & 32,600 \\
\hline 43 & 1,490 & 804 & 941 & 44,400 & 49,300 \\
\hline 46 & 1,420 & 1,090 & 937 & 57,300 & 46,900 \\
\hline 48 & 2,030 & 750 & 873 & 56,400 & 59,300 \\
\hline 52 & 1,780 & 774 & 748 & 51,000 & 44,700 \\
\hline 53 & 1,120 & 883 & 822 & 36,600 & 30,700 \\
\hline 54 & 1,030 & 2,680 & 782 & 102,000 & 29,800 \\
\hline 56 & 1,220 & 732 & 780 & 33,100 & 35,200 \\
\hline 58 & 1,220 & 909 & 911 & 41,100 & 41,200 \\
\hline 60 & 817 & 866 & 853 & 26,200 & 25,800 \\
\hline 62 & 564 & 1,320 & 1,070 & 27,600 & 22,400 \\
\hline 63 & 709 & 836 & 830 & 22,000 & 21,800 \\
\hline 64 & 915 & 907 & 877 & 30,700 & 29,700 \\
\hline 65 & 1,450 & 766 & 792 & 41,100 & 42,500 \\
\hline 68 & 1,580 & 818 & 860 & 47,900 & 50,300 \\
\hline 69 & 1,090 & 961 & 938 & 38,800 & 37,900 \\
\hline 70 & 1,880 & 911 & 1,010 & 63,400 & 70,300 \\
\hline 76 & 1,810 & 877 & 844 & 58,800 & 56,600 \\
\hline 77 & 844 & 1,240 & 1,140 & 38,800 & 35,600 \\
\hline Total & $\overline{41,083}$ & 31,194 & 27,878 & $1,331,700$ & $1,198,100$ \\
\hline
\end{tabular}

measurements made in 1980 and 1994 were made at the same locations.

Quantities of suspended sediment transported in a stream typically are expressed in tons per day. The volumes of sediment estimated to have aggraded in or scoured from the Momence Wetlands reach also were converted to tons for comparison with suspendedsediment transport estimates. The tons of sediment aggraded or scoured were estimated by calculating the specific weight of the sediments in the Momence Wetlands reach based on equations formulated by Lane and Koelzer (1953) and compilations of sediment specific-weight data collected throughout the United States (Vanoni, 1975). In these references, specific weights for sediments primarily composed of sandsized particles ranged from 75 to $109 \mathrm{lb} / \mathrm{ft}^{3}$. The specific weight of the sediments deposited in the Momence Wetlands reach was estimated to be about $93 \mathrm{lb} / \mathrm{ft}^{3}$ or $2,511 \mathrm{lb} / \mathrm{yd}^{3}$. The estimated quantities of sediment aggraded in or scoured from the cross-section segments will be expressed as both cubic yards and tons throughout this report.

The Momence Wetlands reach was divided into thirds for analysis of changes in cross-section geometry 


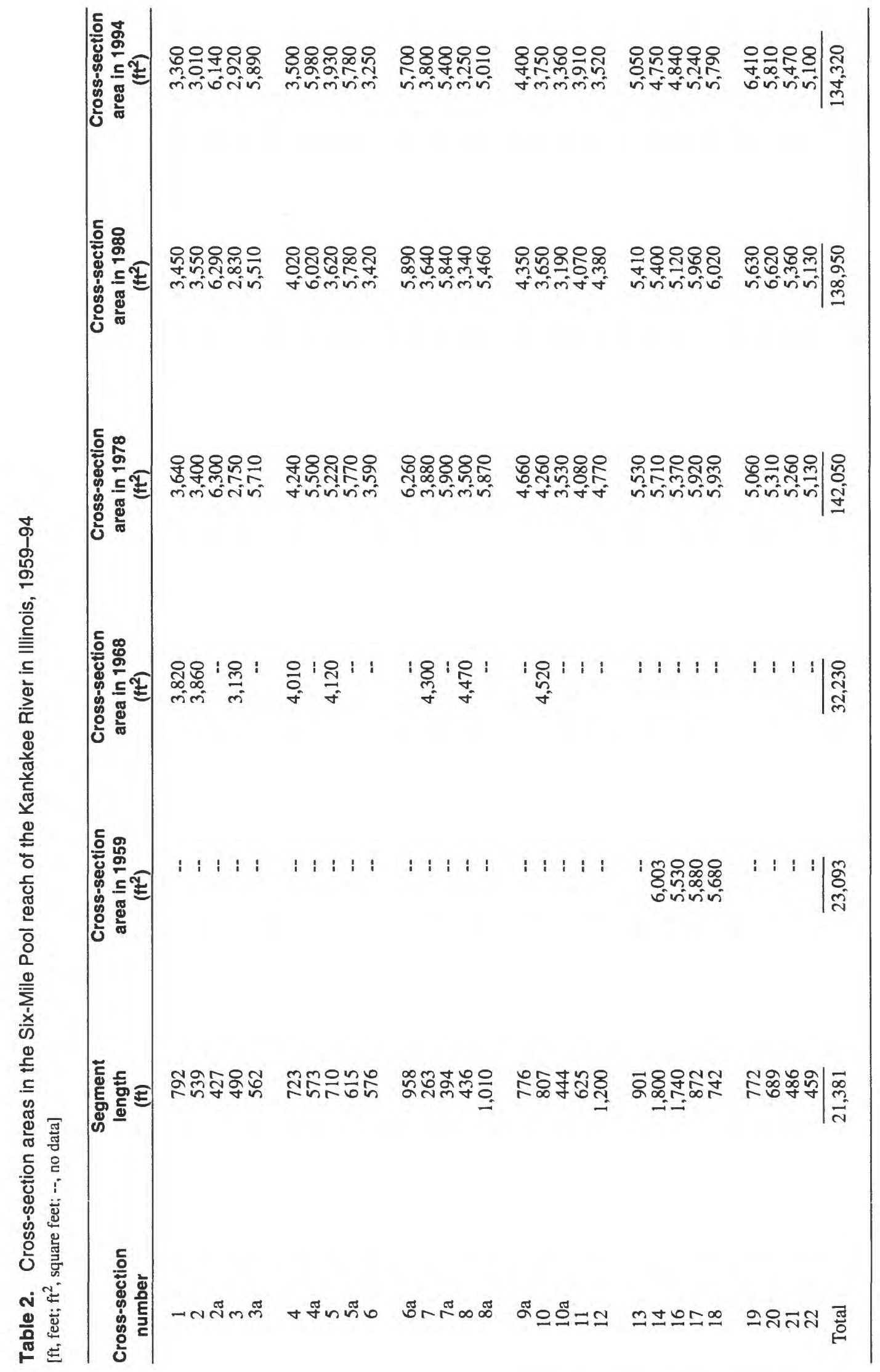




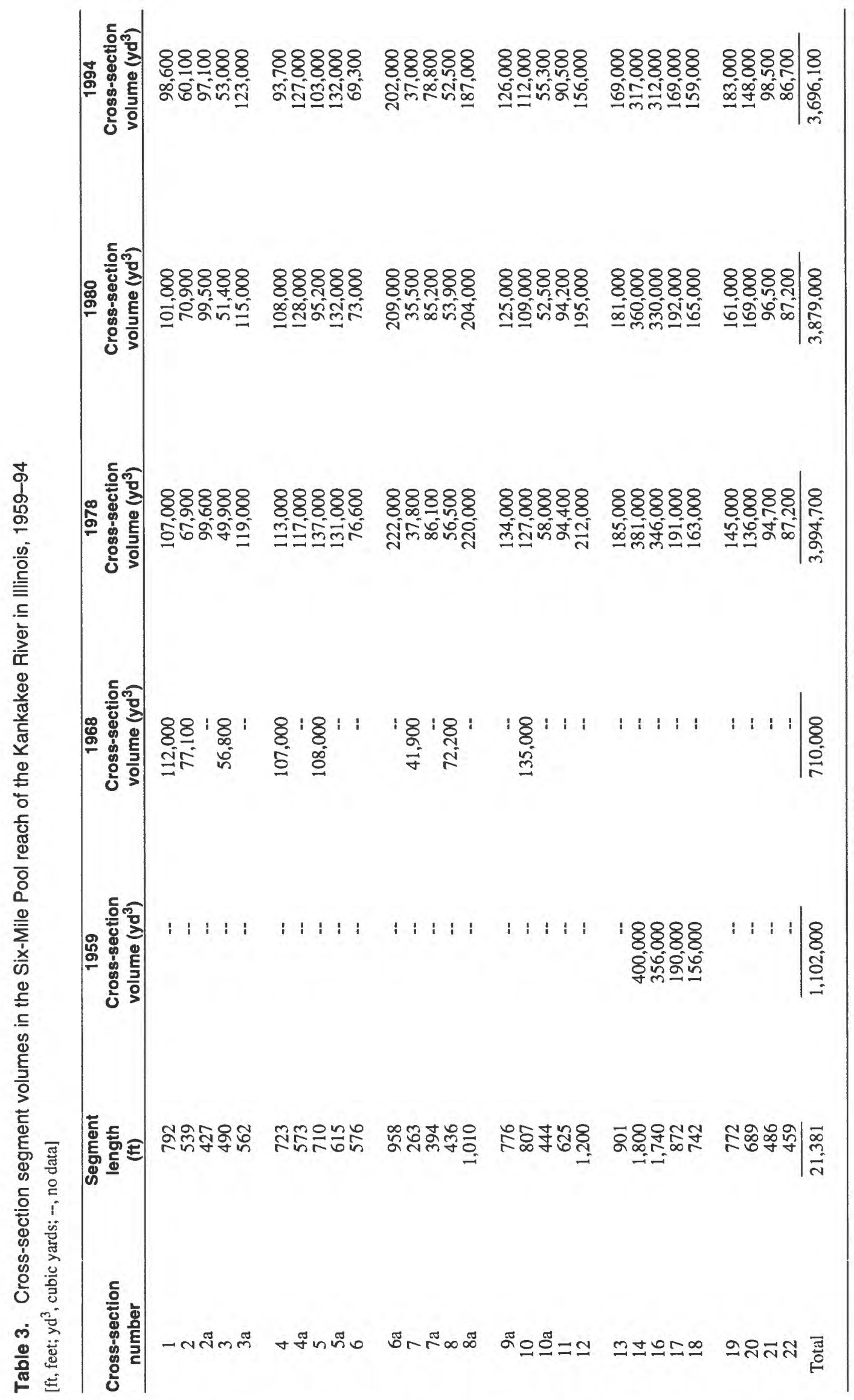



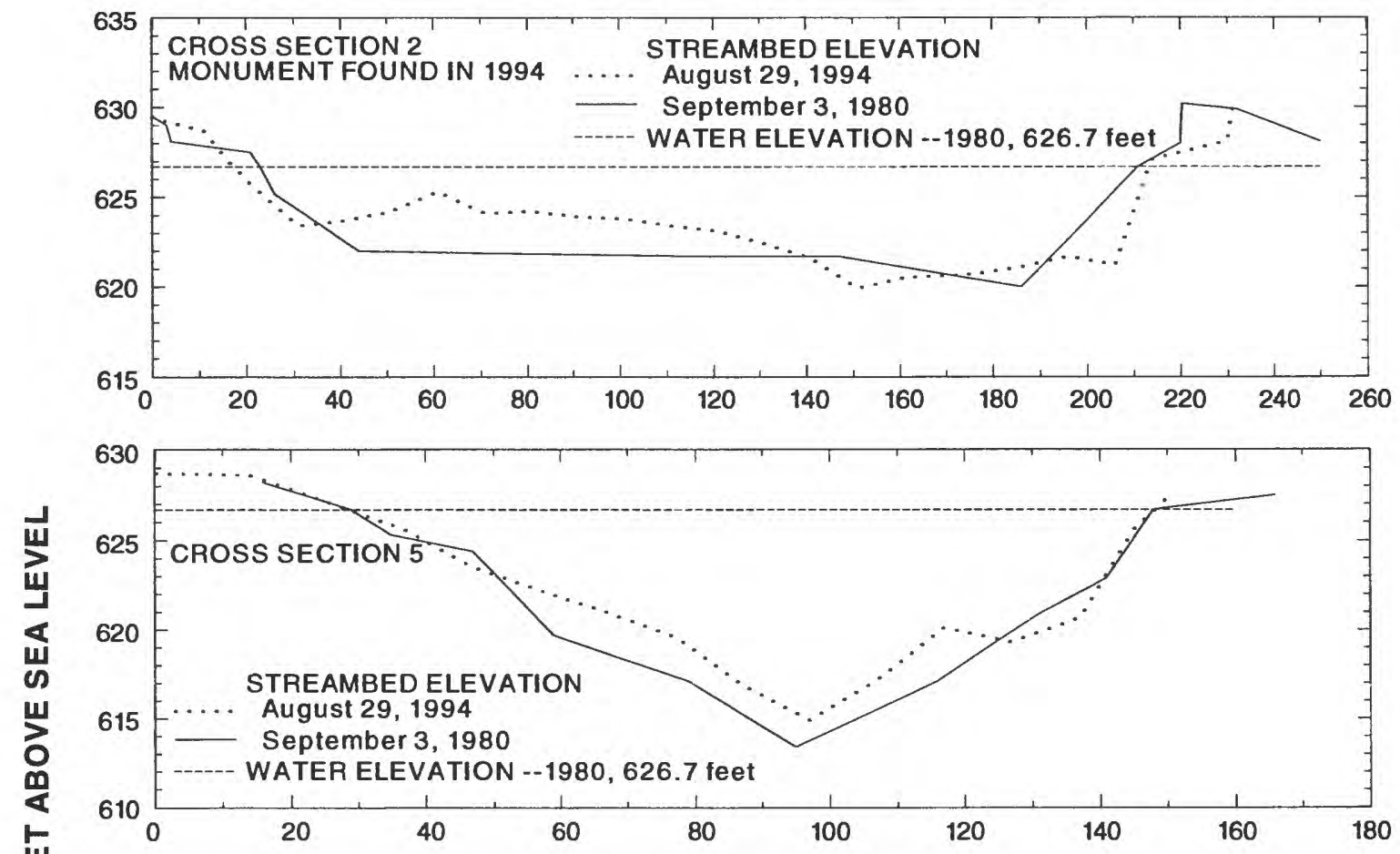

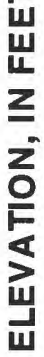
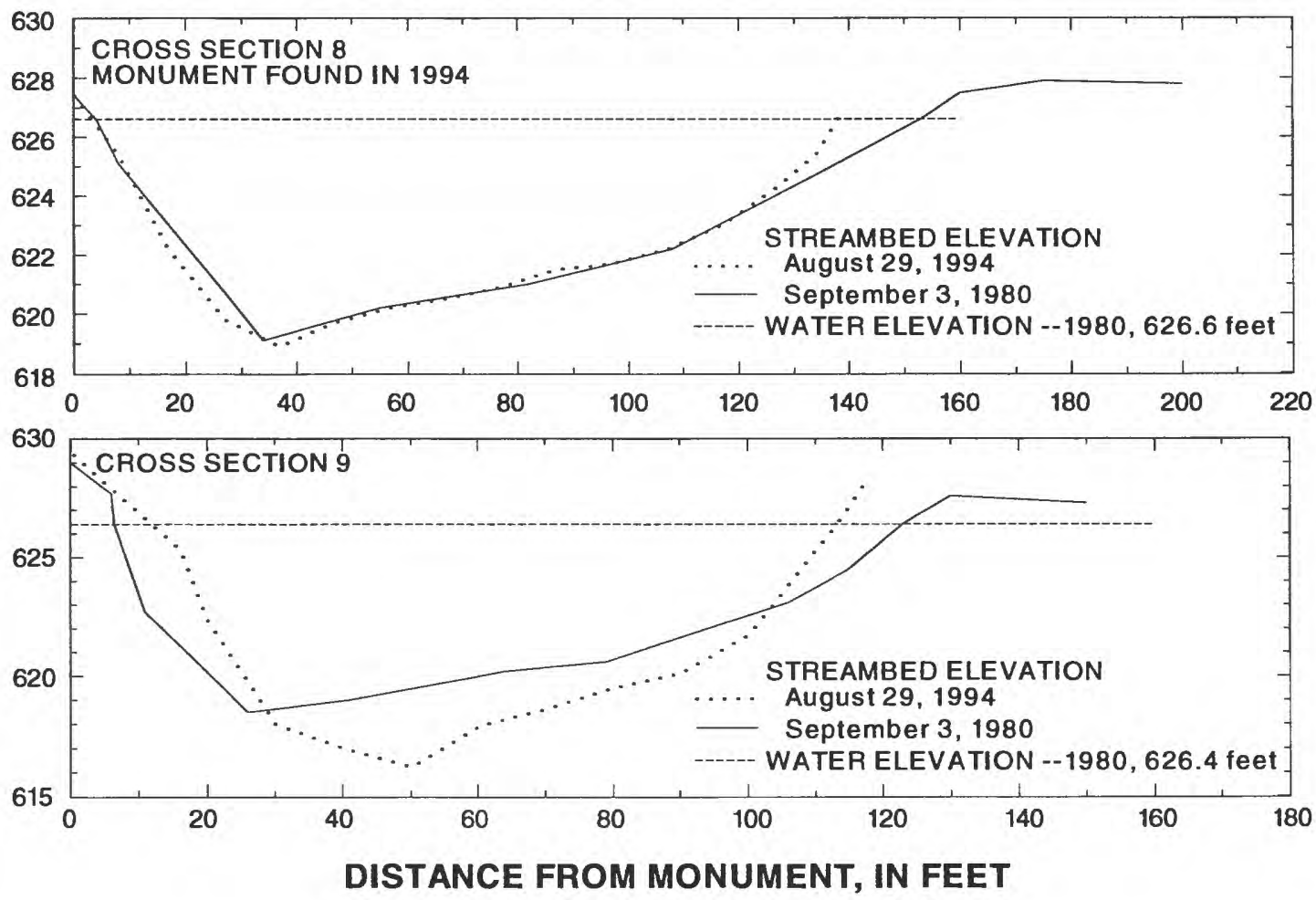

Figure 7. Cross-section geometry in 1980 and 1994 at the 35 cross sections in the Momence Wetlands reach of the Kankakee River in Illinois, view looking downstream. 

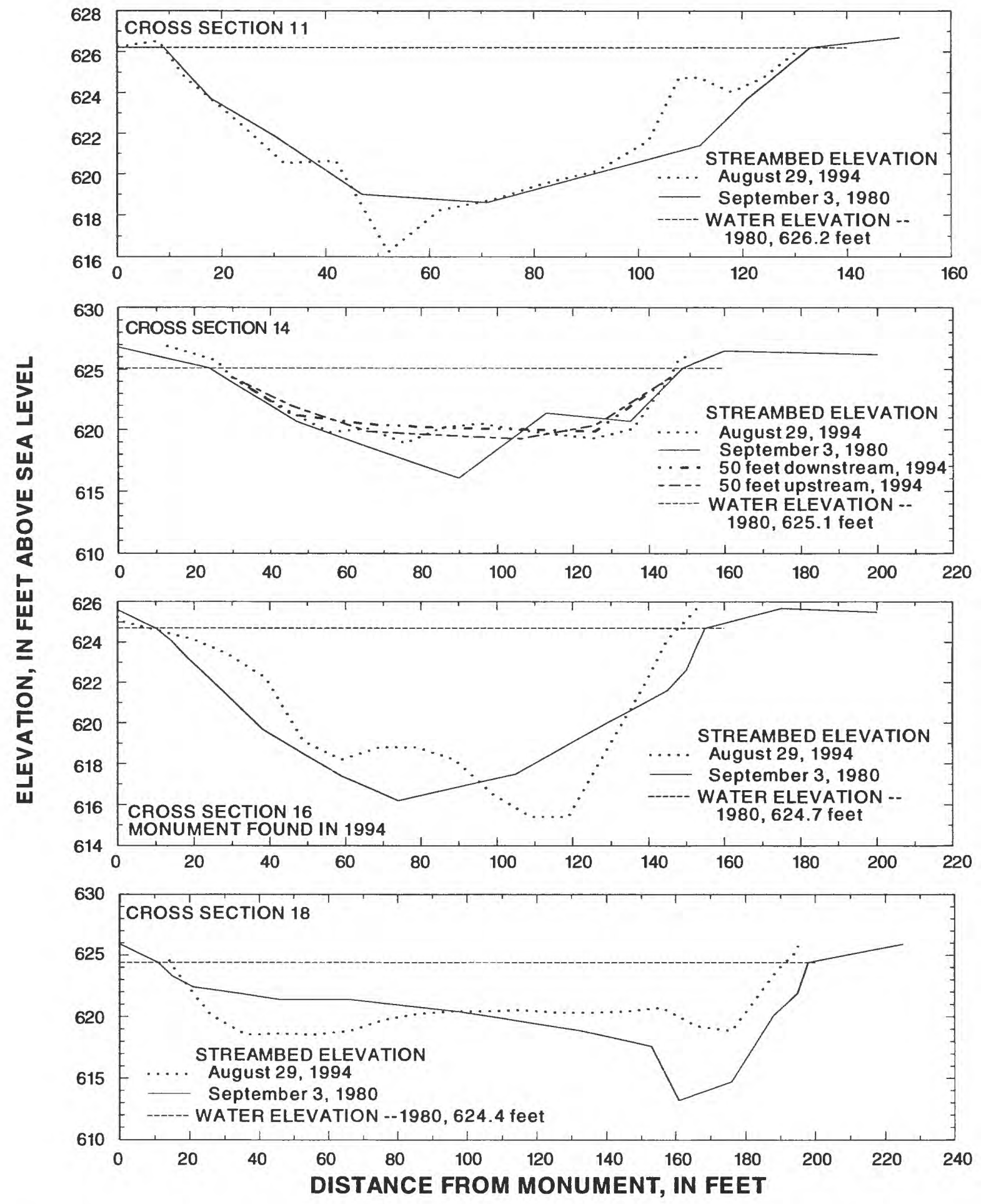

Figure 7. Continued. 

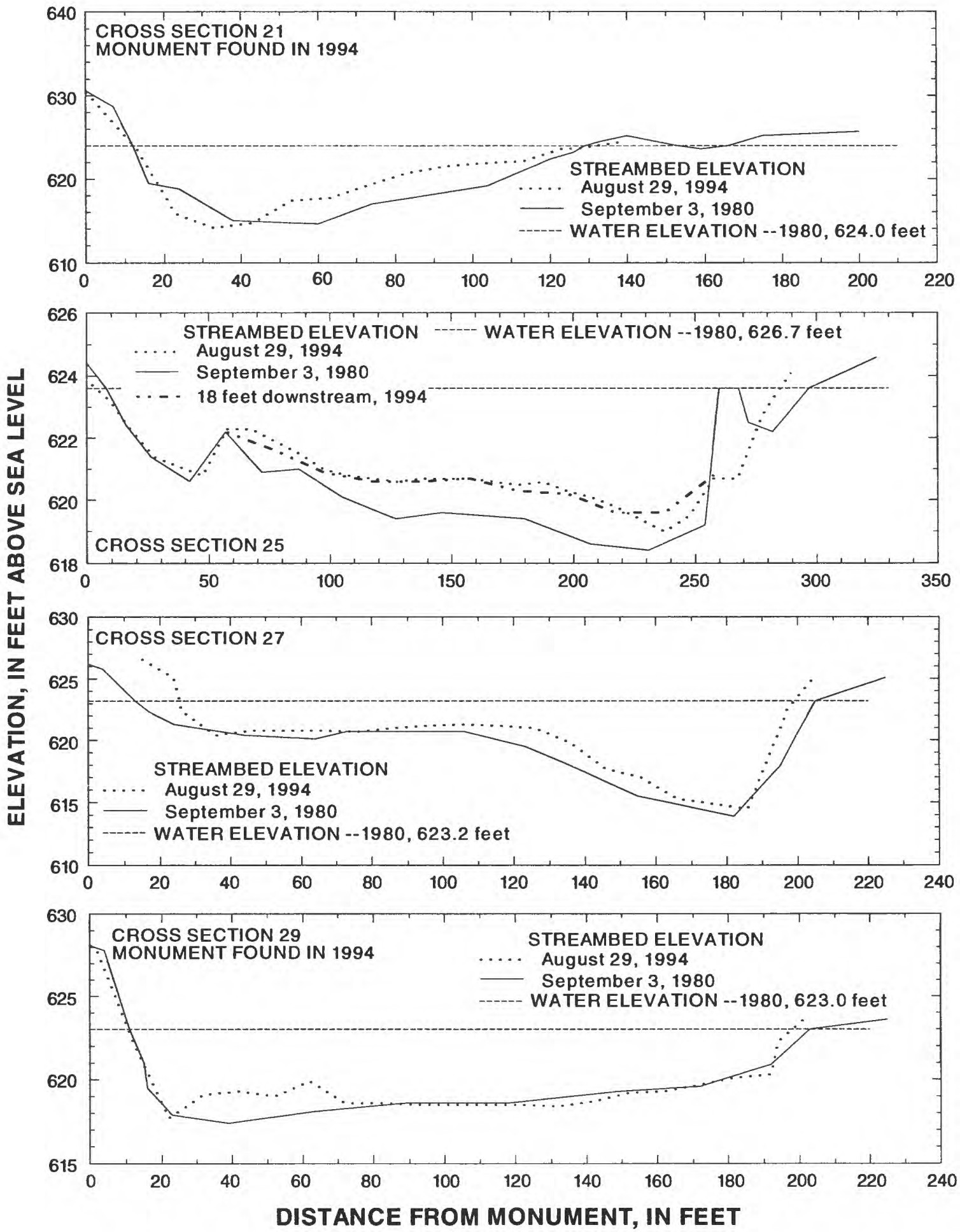

Figure 7. Continued 

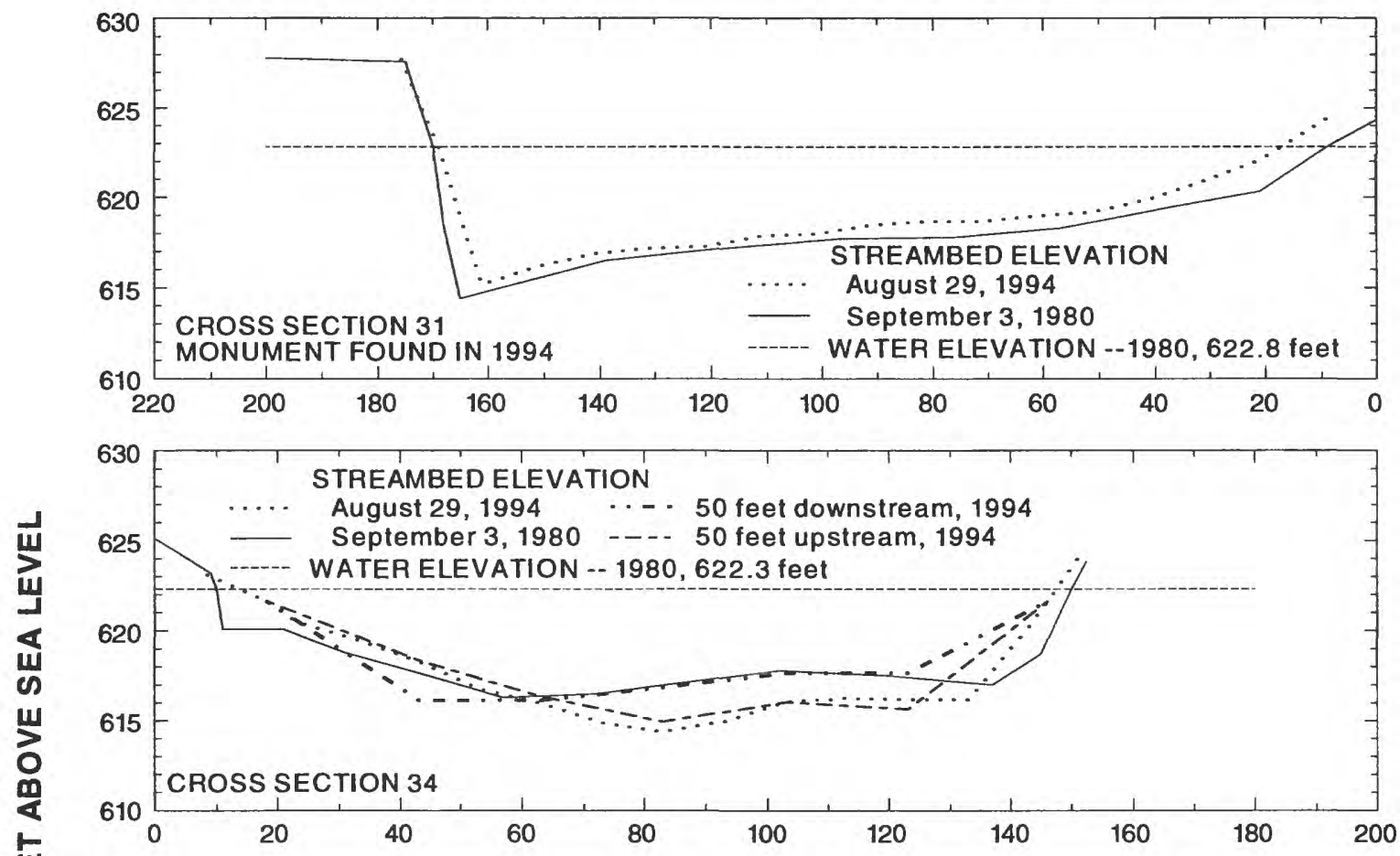

2
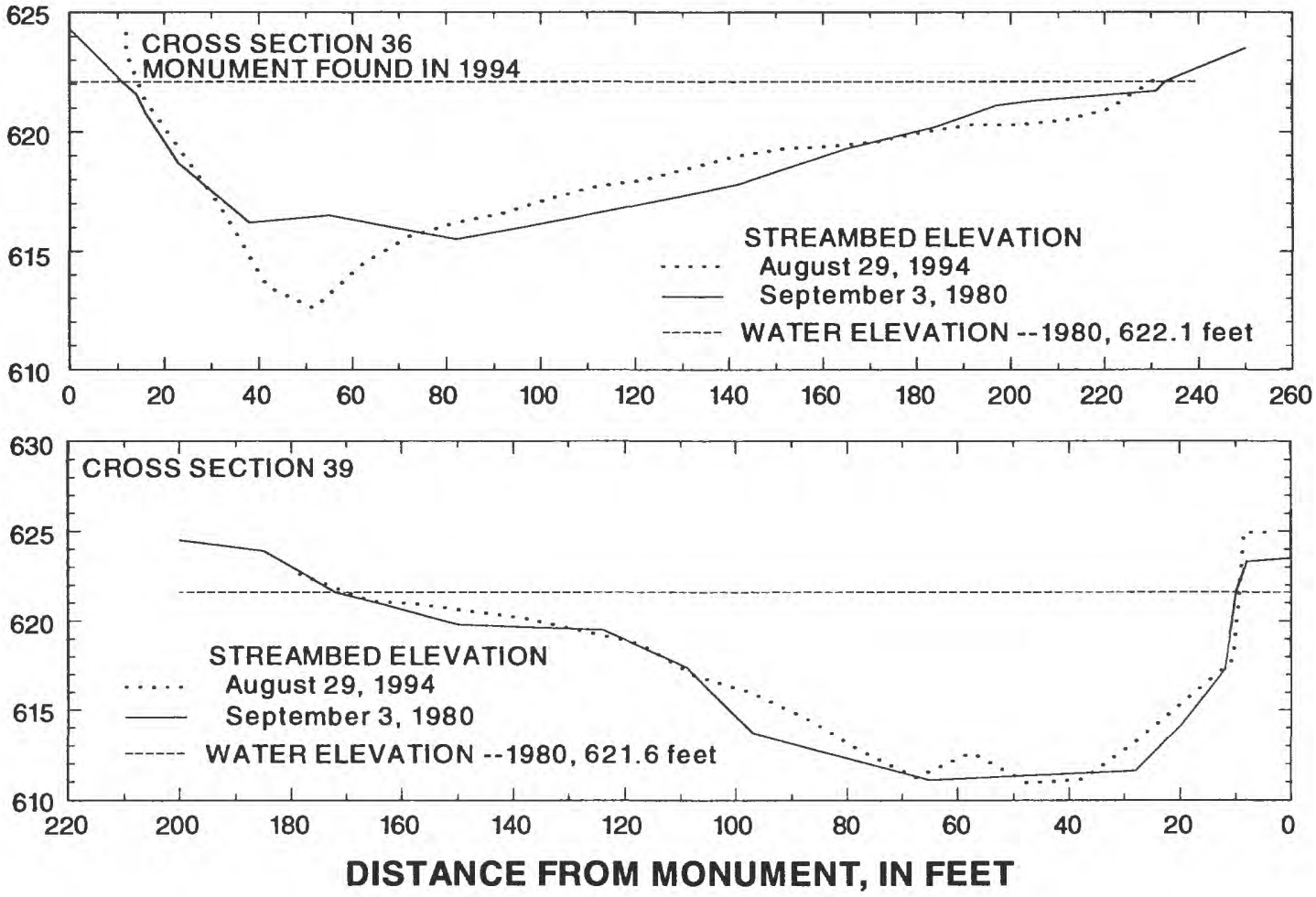

Figure 7. Continued. 

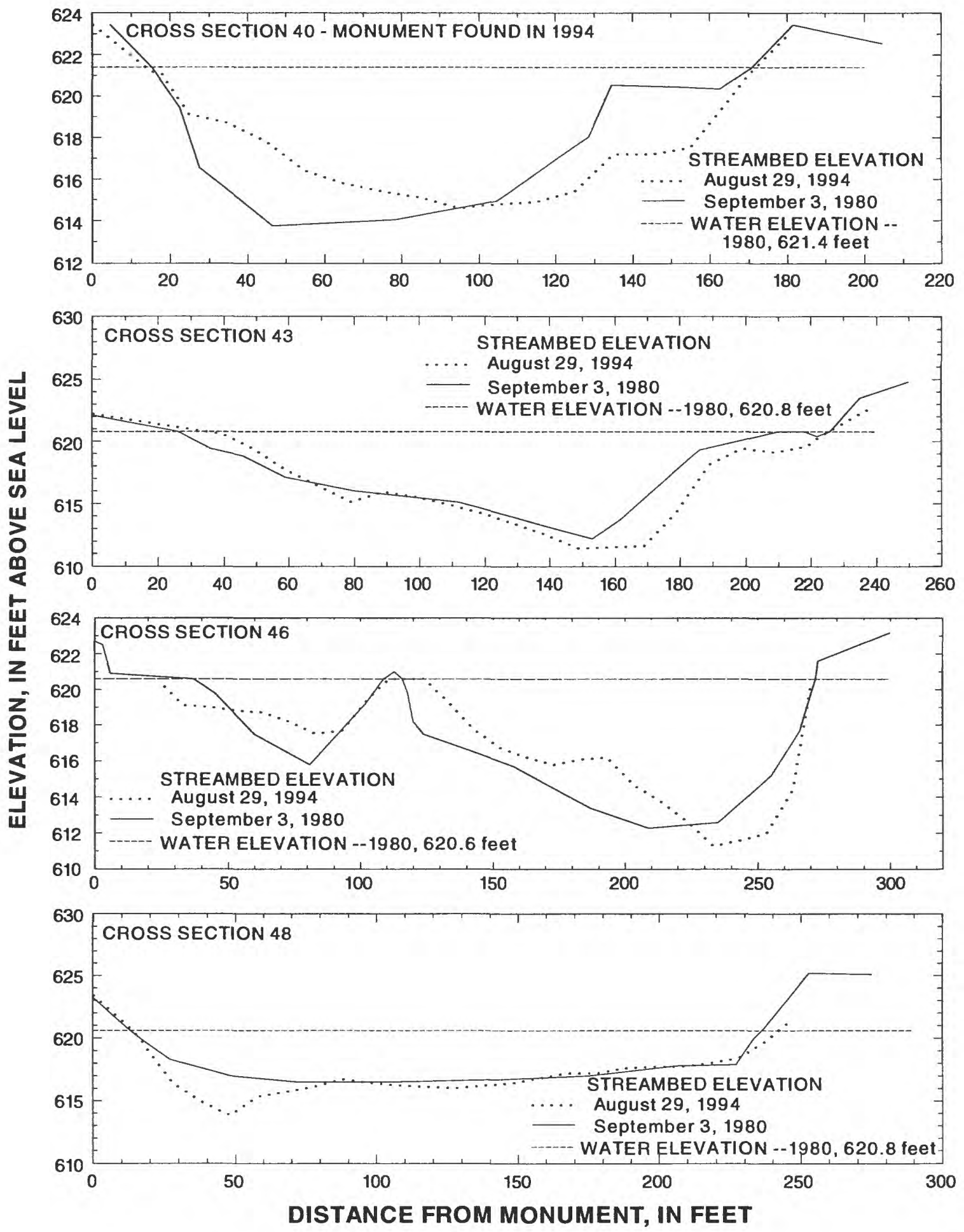

Figure 7. Continued. 

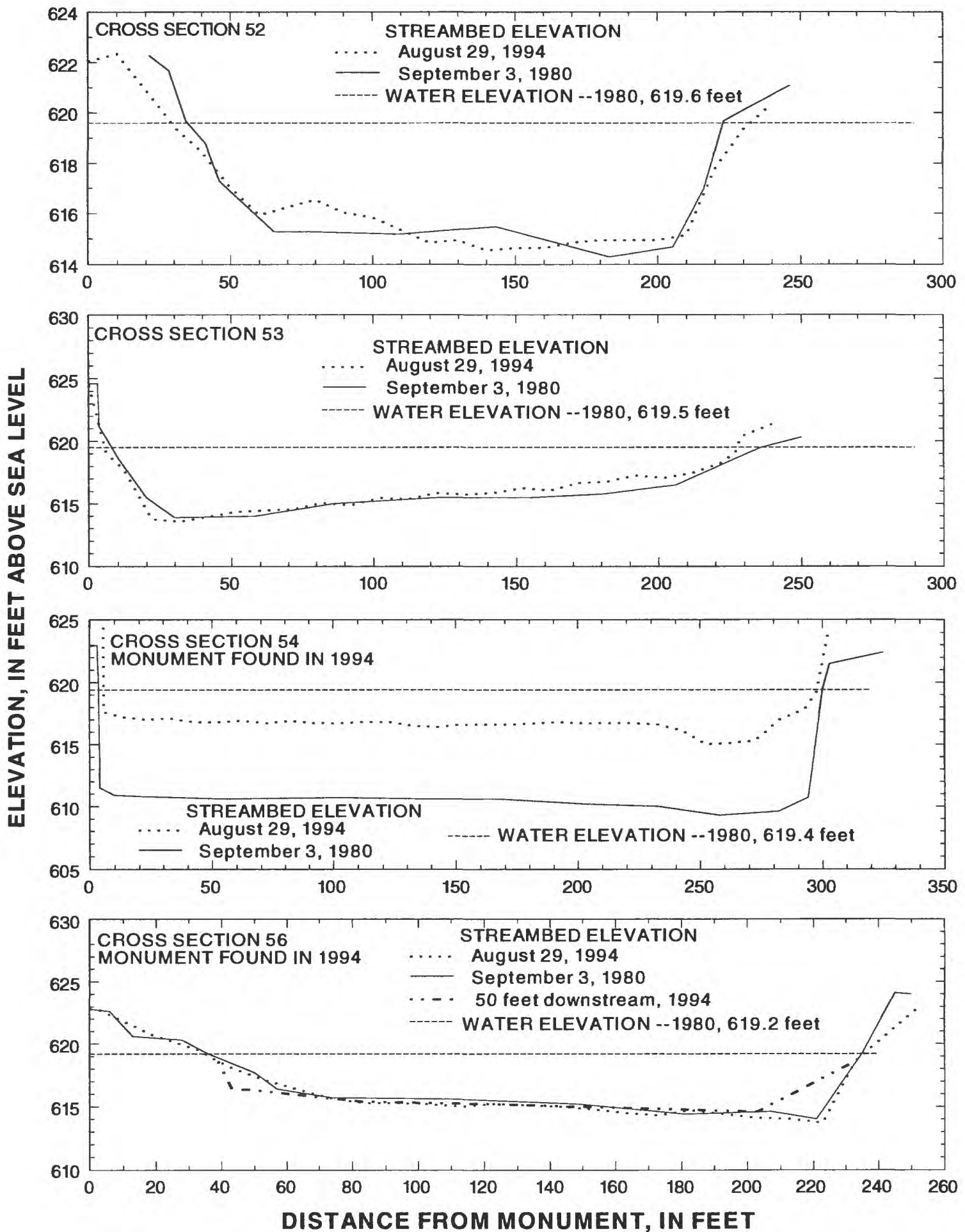

Figure 7. Continued. 

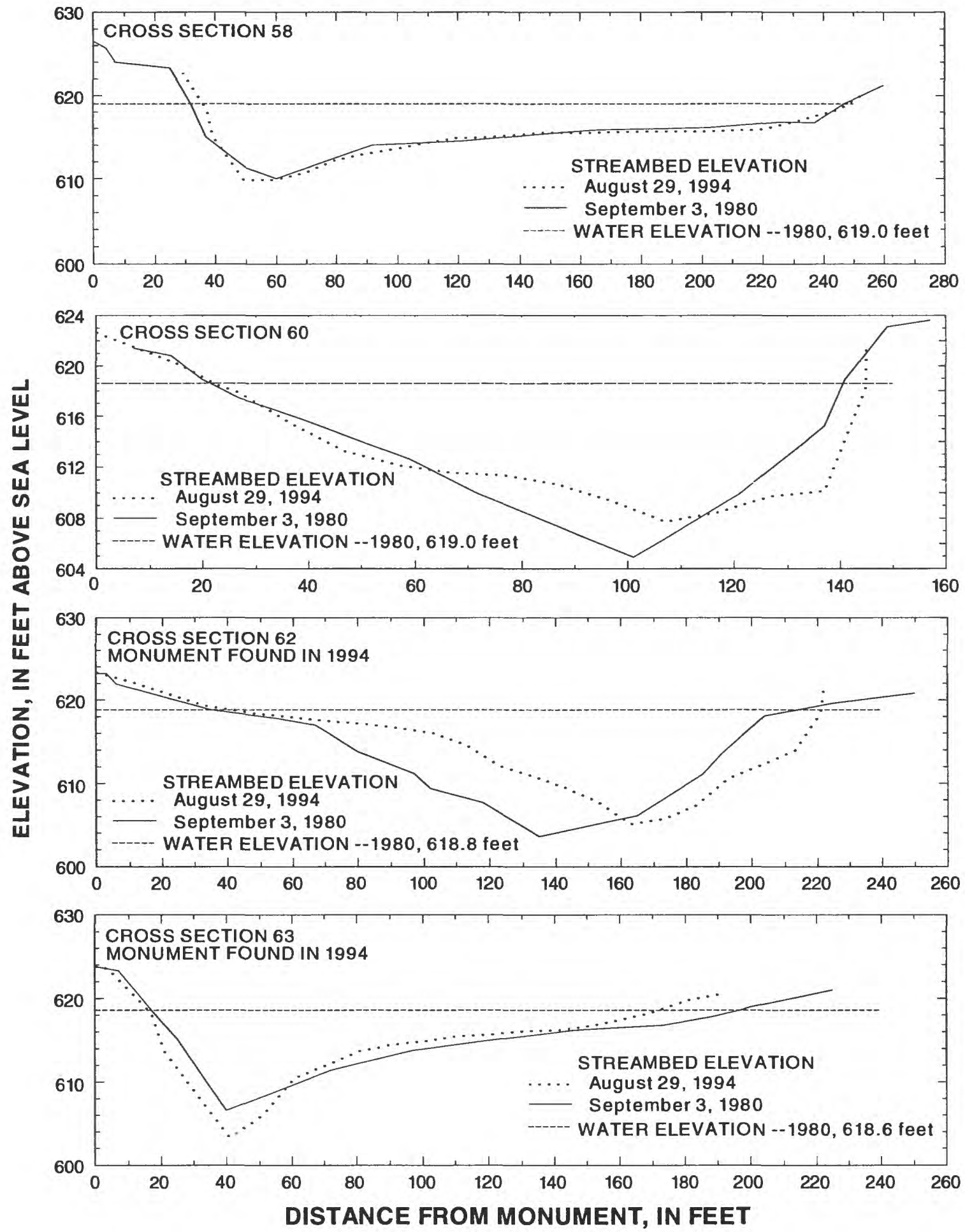

Figure 7. Continued. 

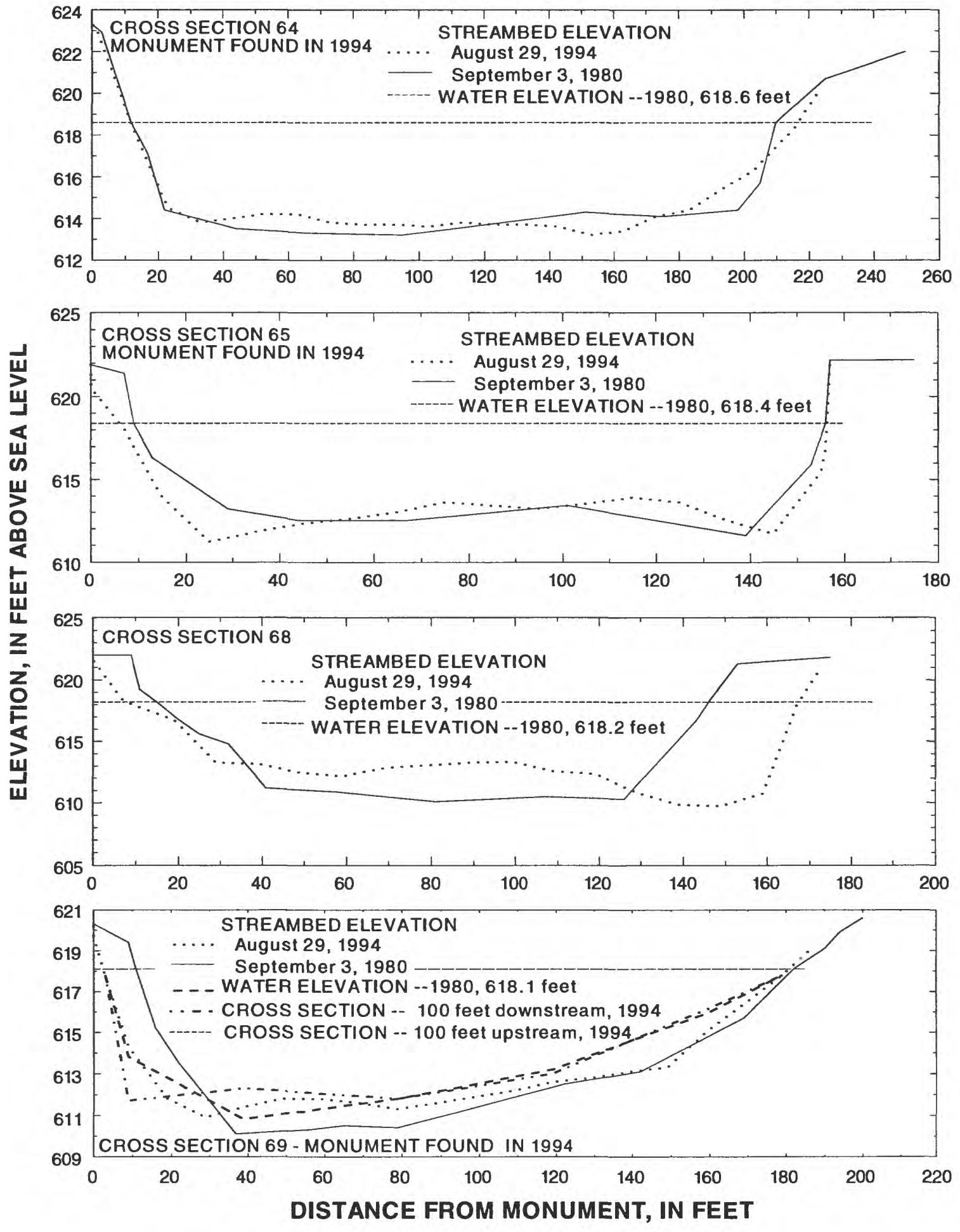

Figure 7. Continued. 

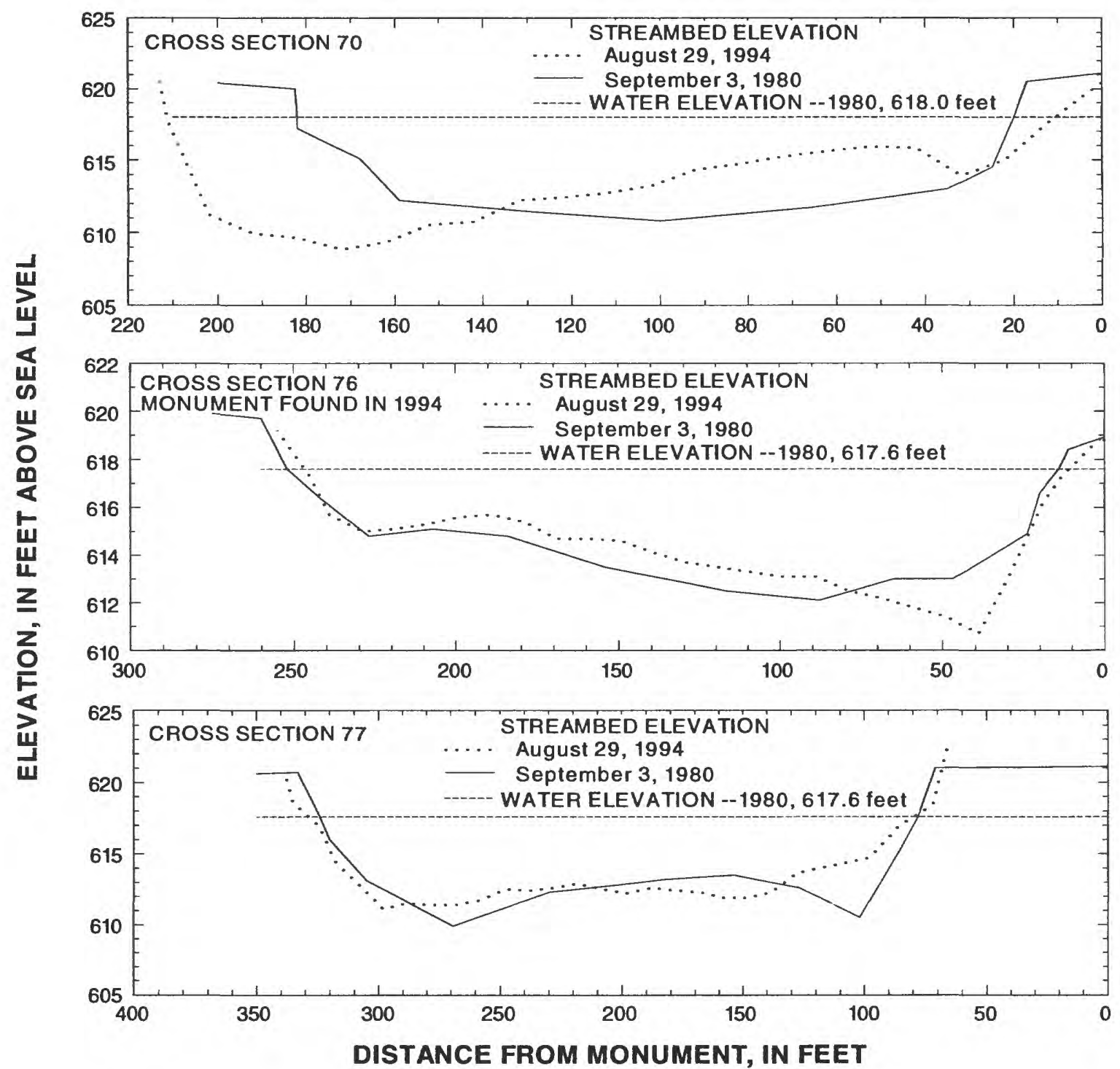

Figure 7. Continued.

and channel volume (fig. 3). The division of the reach into thirds allowed a summary analysis of the reach that showed the predominant changes that occurred within the reach. The reach was divided into thirds based on apparent differences in sedimentation characteristics, the number of cross sections included in each third, and the overall stream length included in each third.

Aggradation and a corresponding decrease in channel volume was predominant in the upstream third of the Momence Wetlands reach. Aggradation and scour occurred in the middle and downstream thirds of the reach with slightly reduced magnitudes of change in the downstream third. A net aggradation of about $133,600 \mathrm{yd}^{3}$ (167,700 tons) of sediment resulted in the
Momence Wetlands reach from 1980 to 1994. Aggradation occurred in 25 of the 35 cross-section segments, which resulted in an accumulation of about 159,300 $\mathrm{yd}^{3}$ (200,000 tons) of sediment. Scour occurred in 10 of the cross-section segments, which resulted in the removal of about $25,700 \mathrm{yd}^{3}$ (32,300 tons) of sediment. A summary of changes in channel volume for each third of the Momence Wetlands reach is provided in table 4 .

Aggradation occurred at all but one cross section in the upstream third of the Momence Wetlands reach (cross sections 2-31 (fig. 4)), and the net aggradation was approximately $45,600 \mathrm{yd}^{3}$ ( 57,200 tons) of sediment in this third of the reach. Scour was indicated at 


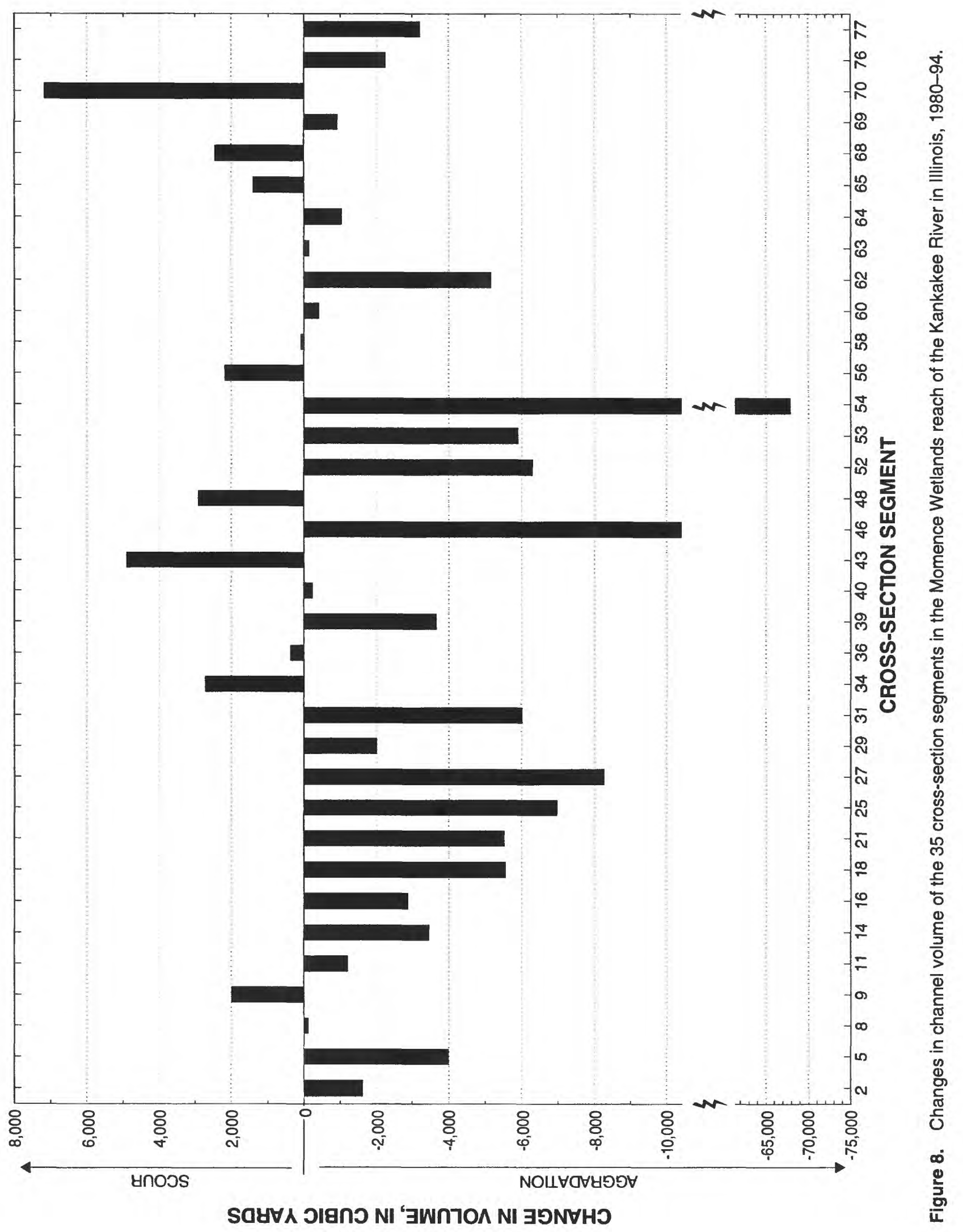


one cross section (cross section 9) in this third of the Momence Wetlands reach. The change in the crosssection segment volume was greater than or equal to 10 percent of the 1980 volume in 9 of the 13 crosssection segments.

Aggradation and scour occurred in the middle third of the Momence Wetlands reach (cross sections 34-56). The net change in this third of the reach was aggradation of about $85,700 \mathrm{yd}^{3}$ (108,000 tons) of sediment. Most of the scour (approximately $12,900 \mathrm{yd}^{3}$ or 16,200 tons of sediment) in the Momence Wetlands reach occurred in this third of the reach. Aggradation of about $98,600 \mathrm{yd}^{3}$ (124,000 tons) of sediment also occurred in this third of the reach. The aggradation amounted to greater than or equal to 10 percent of the 1980 volume in 5 of the 11 segments in this third, whereas the scour in two segments was greater than or equal to 10 percent of the 1980 volume.

Aggradation of about $72,200 \mathrm{yd}^{3}$ (90,600 tons) of sediment was indicated at one cross-section segment (54). Cross-section segment 54 was located in a relatively straight part of the channel compared to most of the channel throughout the Momence Wetlands. Channel modifications, including increasing the height of a retaining wall, had been made to the streambank on each side of the river by local residents. The monument at cross section 54 was buried by approximately $1.5 \mathrm{ft}$ of fill material placed behind the retaining wall. Changes in cross-section geometry and the loss of channel depth at this cross section were attested to by local residents. This section of the channel was resurveyed by the USGS in April 1996 to verify the previous measurements and findings. The resurvey indicated slight movement of the monument for cross section 54 (lowered by $0.4 \mathrm{ft}$ ), but substantial aggradation of sediment had occurred. A decrease in the slope of the water-surface profile from the upstream third of the Momence Wetlands reach through the middle third of the reach is depicted in figure 4. An abrupt break in the slope is shown between monuments 54 and 56 . The slope of the water-surface profile through the downstream third of the reach is less than through the middle third. The abrupt break in slope between monuments 54 and 56, and the documented aggradation of sediment at cross section 54 could indicate the front edge of a slug of sediment or sand bar accumulating in or moving through this part of the channel; a process documented in other parts of the Momence Wetlands by Bhowmik and others (1980).

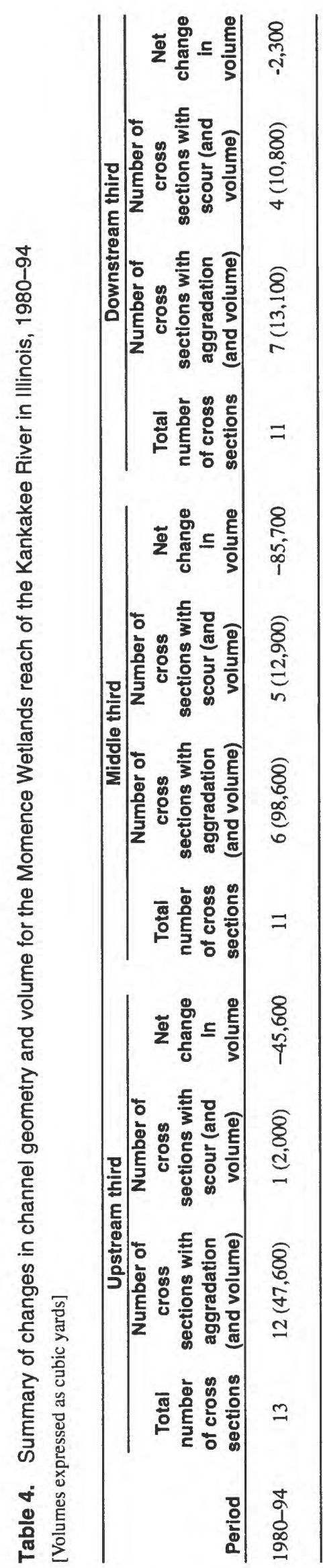


Changes in cross-section geometry and channel volume in the downstream third of the Momence Wetlands reach (cross sections 58-77) were not as marked as in the other two-thirds of the reach. In the downstream third, aggradation of approximately $13,100 \mathrm{yd}^{3}$ (16,450 tons) of sediment and scour of approximately $10,800 \mathrm{yd}^{3}(13,600$ tons) of sediment yielded a net aggradation of approximately $2,300 \mathrm{yd}^{3}$ (2,890 tons) of sediment. Eleven cross-section segments were included in the downstream third of the reach. There was only one segment in which aggradation was greater than or equal to 10 percent of the 1980 volume and only one segment in which the scour was greater than or equal to 10 percent of the 1980 volume.

Aggradation likely results in the upstream onethird of the Momence Wetlands reach because of the transition from a straight river channel in Indiana to a mostly natural meandering river channel in Illinois. The slope of the Kankakee River channel in Indiana is approximately $1.06 \mathrm{ft} / \mathrm{mi}$, based on flood-profile data (T.K. Greeman, U.S. Geological Survey, written commun., 1995). The slope of the channel through the Momence Wetlands reach is about $1.6 \mathrm{ft} / \mathrm{mi}, 1.1 \mathrm{ft} / \mathrm{mi}$, and $0.5 \mathrm{ft} / \mathrm{mi}$, respectively, for the upstream, middle, and downstream thirds, based on water-surface elevations. The channelized river in Indiana provides a comparatively efficient conveyance for water and sediment transport compared to the natural channel in Illinois. The capability of the stream to transport sediment through the Momence Wetlands is reduced as a result of a decrease in flow velocity. Consequently, the amount of sediment held in suspension in the water exceeds the capability of the stream to carry sediment, and the excess sediment settles onto the streambed.

Sediment also is transported along the streambed. The downstream movement of a sandbar at the Illinois-Indiana State line was documented by Bhowmik and others (1980). It is reasonable to assume that this process occurs to some extent on a continual basis throughout the Momence Wetlands reach. This process likely contributes to the change in crosssection geometry and the decreases in channel depths noted by local residents and users of the river.

\section{Six-Mile Pool Reach}

Cross-section measurements of the Six-Mile Pool reach were made periodically from 1959 to 1994. Data from these measurements allow an analysis of changes in cross-section geometry and channel volume over a period of 3 decades. Similar to the river channel in the Momence Wetlands, the morphology of the SixMile Pool is in a dynamic process of change. The comparisons of cross-section measurements indicate only the net change between the measurement times. Changes in the Six-Mile Pool reach can be more readily determined than in the Momence Wetlands reach because measurements were made five times from 1959 to 1994 . The locations of the 29 cross sections in the Six-Mile Pool reach are shown in figure 5.

Graphs of the cross-section geometry at 29 cross sections in the Six-Mile Pool reach for 1959, 1968, 1978, 1980, and 1994 are shown in figure 9. Three cross sections previously measured are not included in the analysis - one cross section was not measured in 1994 , the data for a second cross section was found to contain errors and was not used, and the third cross section was excluded because only one-half of the cross section could be measured because of shallow water on one side of an island. The Fathometer used to make the cross-section measurements in 1994 did not provide accurate depth information when depths were less than about $3 \mathrm{ft}$. Cross-section geometry for the edges of the channel, therefore, was estimated based on historical and 1994 geometry, channel characteristics, hydrologic judgement and interpretation, field notes. and observations. Field notes from the 1994 measurements included estimated distances from the stopping point of the Fathometer readings to the edge of the water on each side of the channel and along the islands. Matching of cross-section plots from different years was based on visual interpretation, field notes, and observations. The cross-section plots were adjusted horizontally but not vertically, and the adjustments did not affect calculations of cross-section area or channel volume.

The water-surface elevation in 1994 was used as the upper boundary for the cross-section area calculations. The 1980 cross-section measurements did not extend above the 1994 water-surface elevation for many of the cross sections, and extrapolation and interpretation of the 1994 geometry above the 1994 watersurface elevation would have introduced additional uncertainty into the calculations and analysis. Crosssection segments for the Six-Mile Pool reach were determined in the same manner as for the Momence Wetlands reach.

The Six-Mile Pool reach, as with the Momence Wetlands reach, was divided into thirds for analysis. 


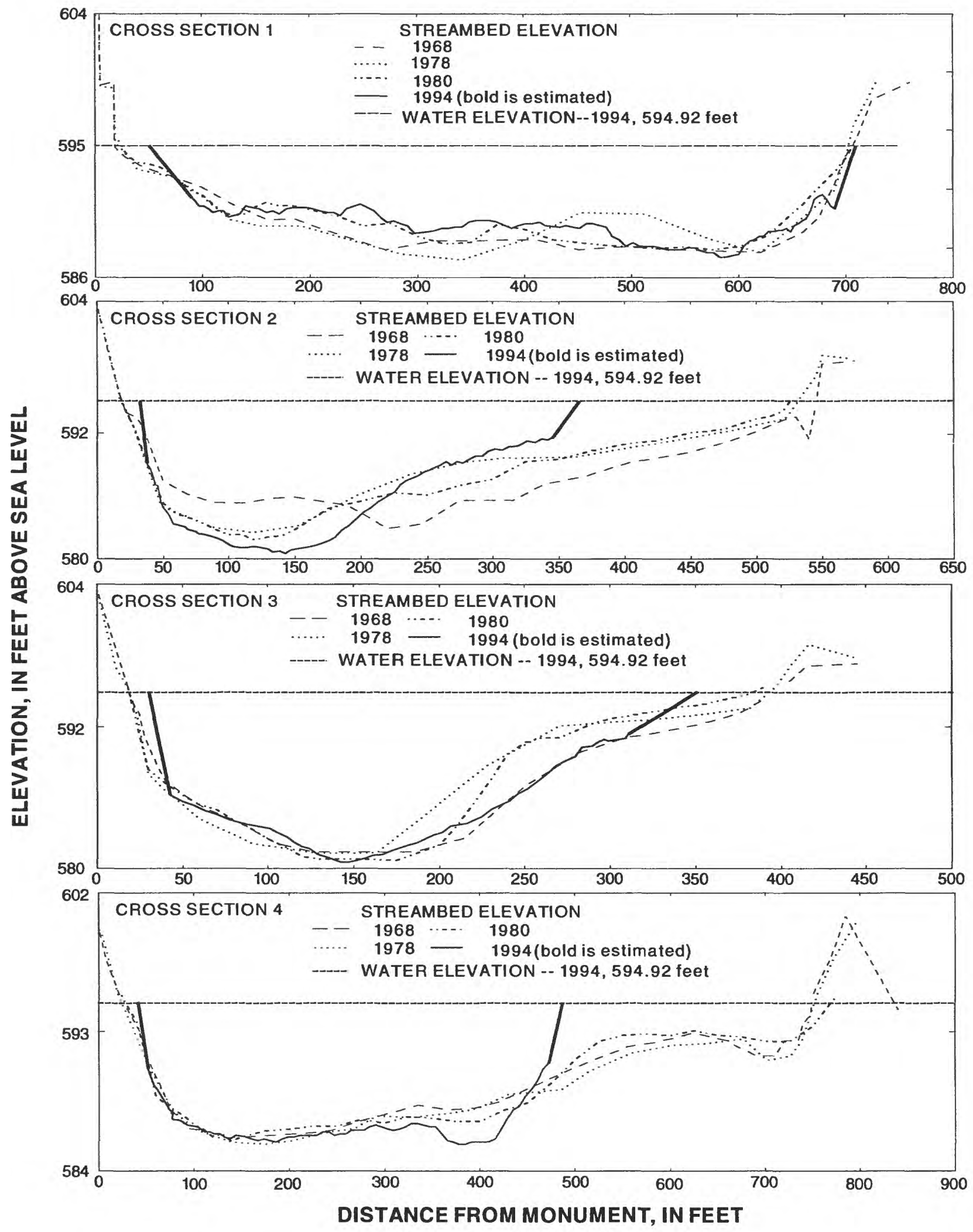

Figure 9. Cross-section geometry in 1959, 1968, 1978, 1980, and 1994 at the 29 cross sections in the Six-Mile Pool reach of the Kankakee River in Illinois, view looking downstream. 

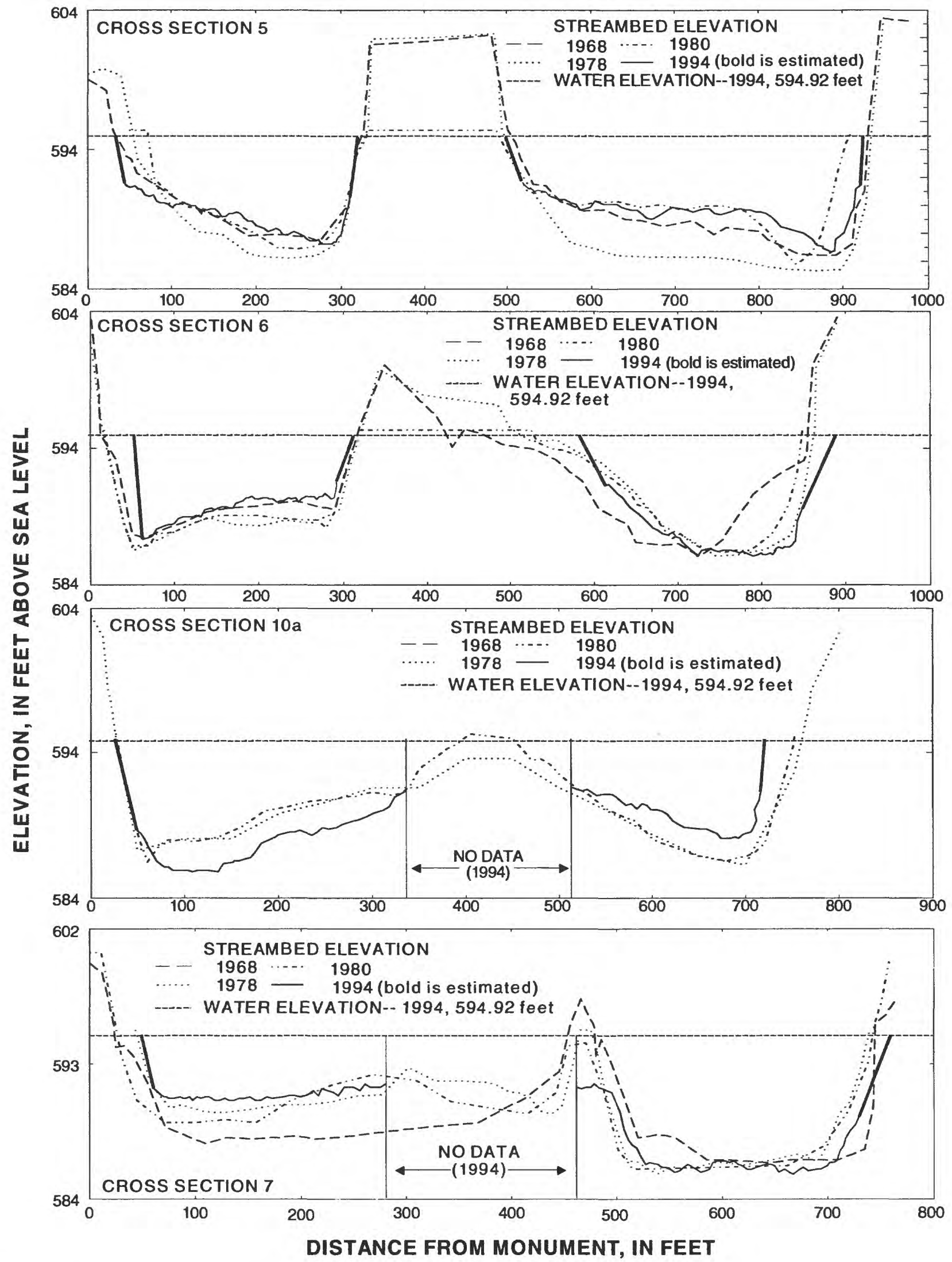

Figure 9. Continued 



Figure 9. Continued. 


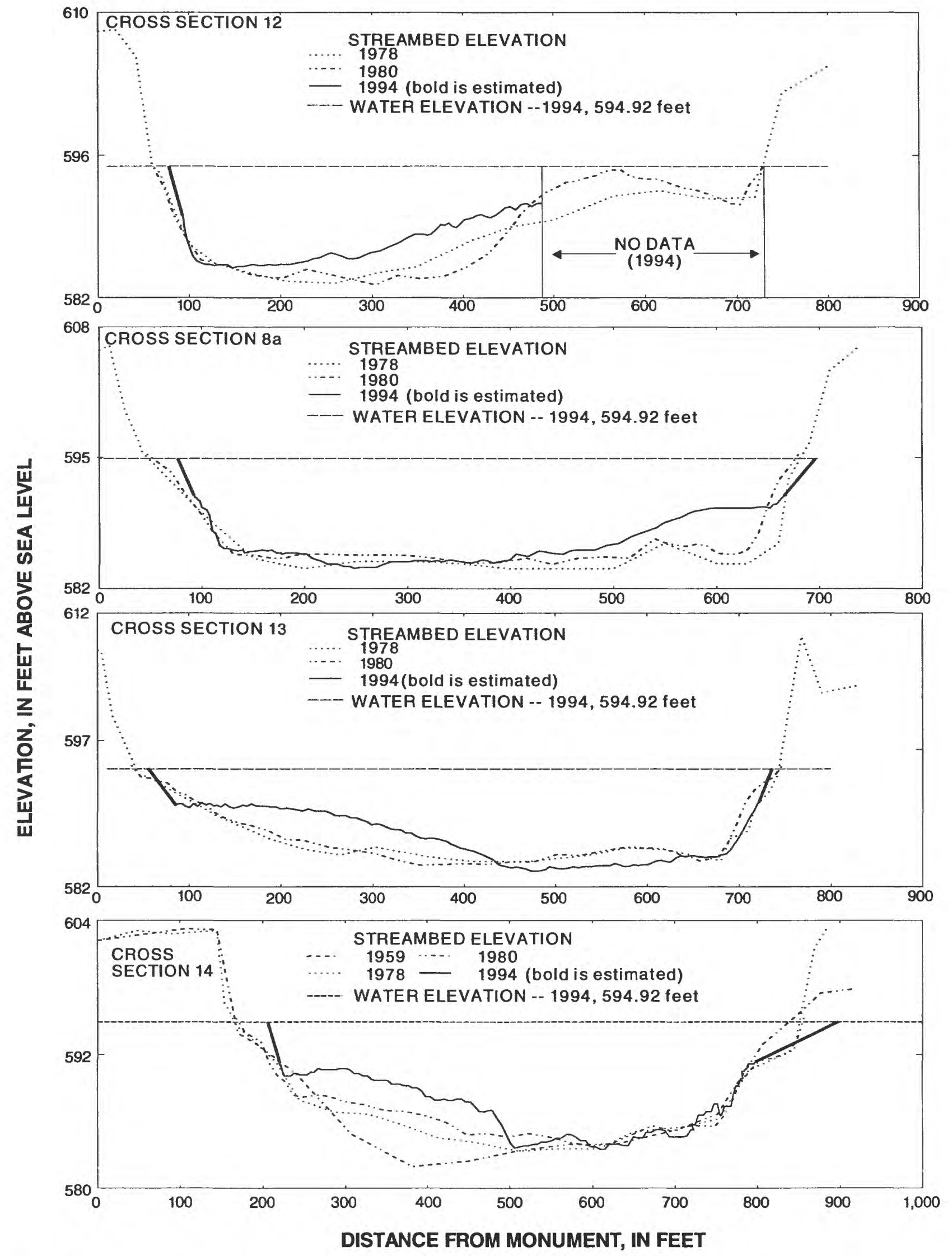

Figure 9. Continued. 

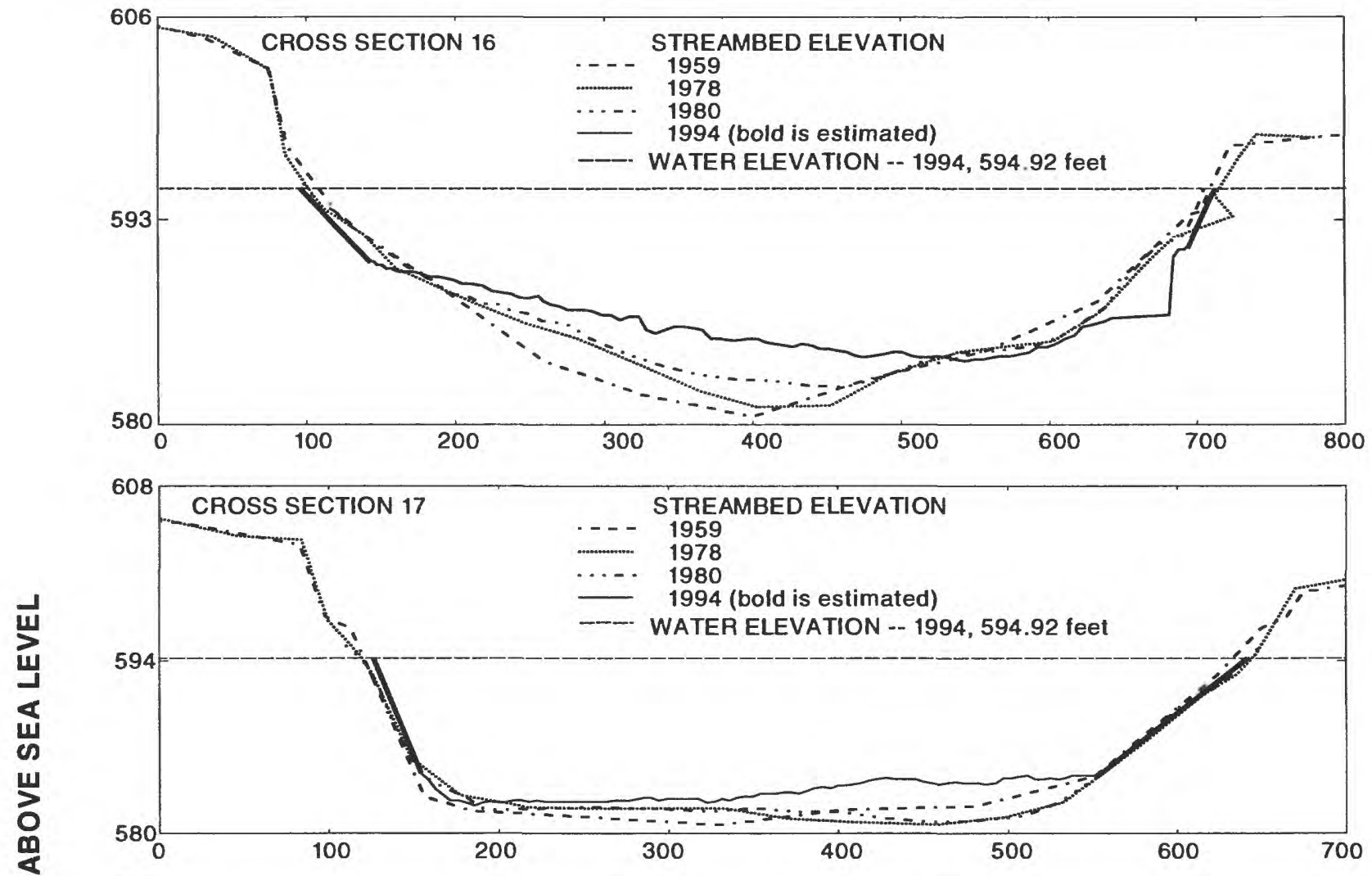

는
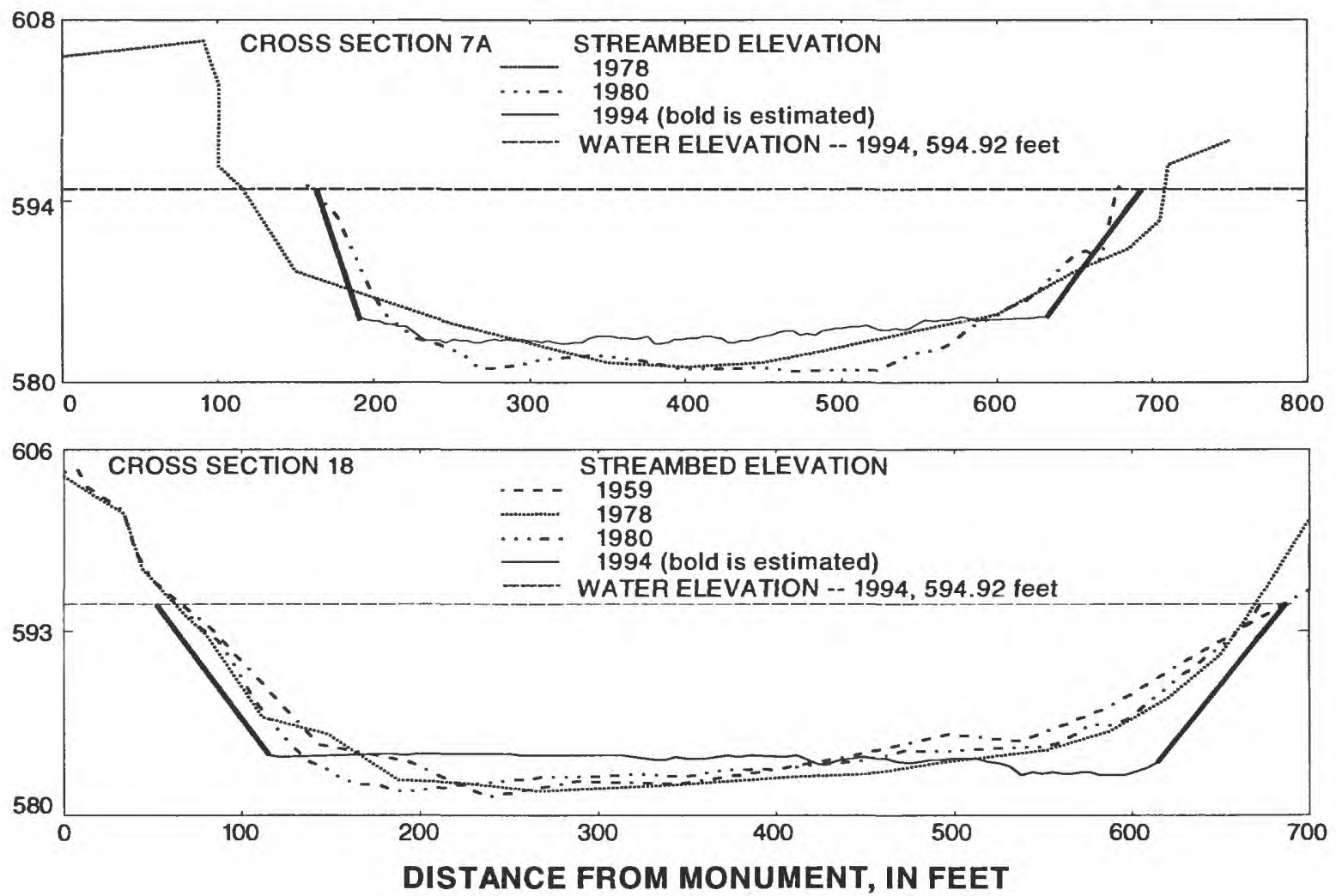

Figure 9. Continued. 

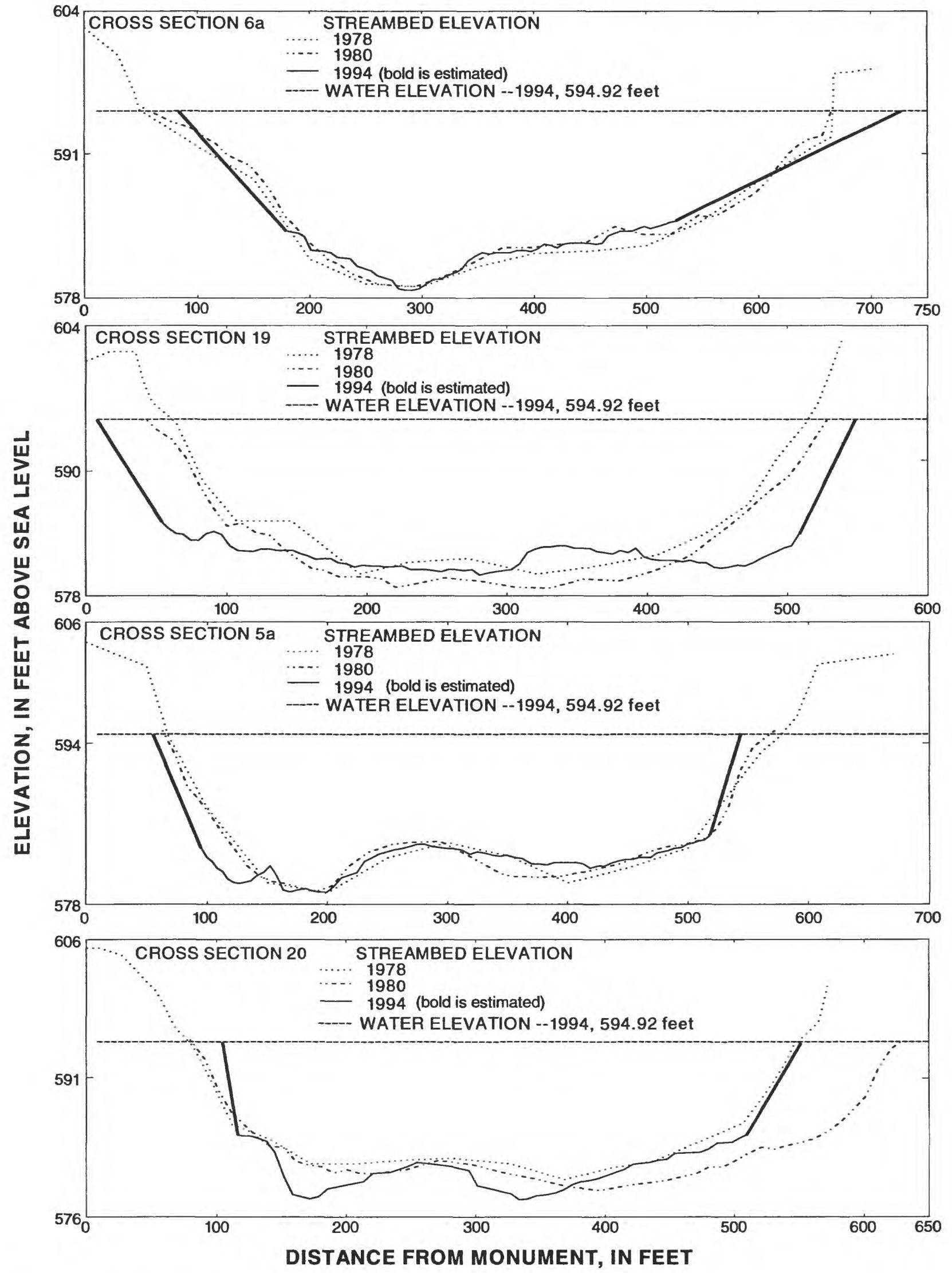

Figure 9. Continued. 


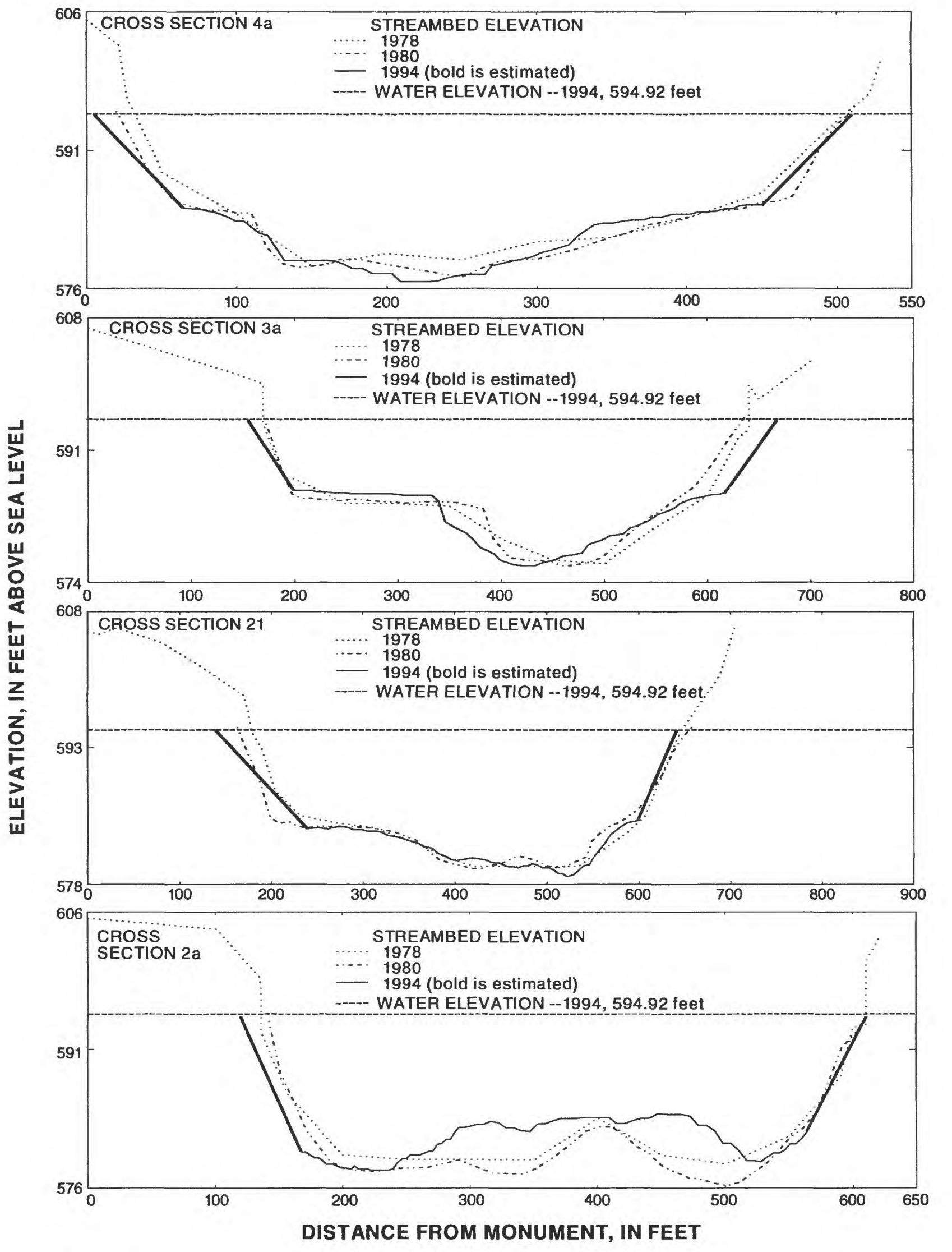

Figure 9. Continued. 


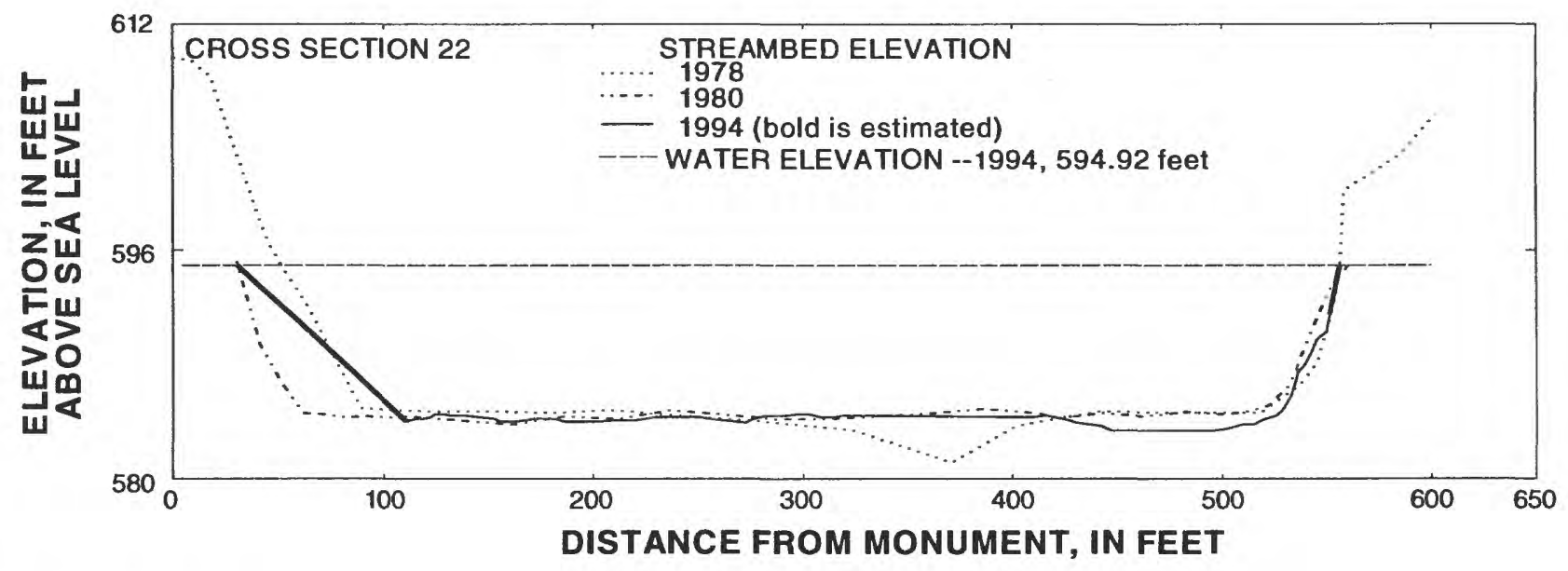

Figure 9. Continued.

These divisions were based on cross-section segment lengths, the number of cross sections in each third, and apparent differences in sedimentation characteristics. These divisions also facilitated the analyses of the limited number of measurements made in 1959 and 1968. Measurements were made at only five cross sections in the middle third of the reach in 1959 and at only nine cross sections in the upstream third of the reach in 1968.

\section{Period from 1980 to 1994}

Net aggradation of approximately $182,900 \mathrm{yd}^{3}$ $(229,600$ tons) of sediment accumulated in the reach from 1980 to 1994 (fig. 10). This net aggradation resulted from the aggradation of approximately $232,600 \mathrm{yd}^{3}$ (292,000 tons) of sediment and the scour of approximately $49,700 \mathrm{yd}^{3}$ ( 62,400 tons) of sediment. A summary of changes in channel volume for each third of the Six-Mile Pool reach is provided in table 5 .

Aggradation and scour occurred in the upstream third of the Six-Mile Pool reach (cross sections 1-9a) from 1980 to 1994 with a net aggradation of about $14,900 \mathrm{yd}^{3}$ (18,700 tons) of sediment. Aggradation of approximately $32,600 \mathrm{yd}^{3}$ (40,900 tons) of sediment occurred in five cross-section segments, and scour of about $17,700 \mathrm{yd}^{3}$ (22,200 tons) of sediment occurred in six segments. Two cross-section segments had aggradation greater than 10 percent of the 1980 volume.

Most of the change in channel volume in the Six-Mile Pool reach occurred in the middle third of the reach (cross sections $6 \mathrm{a}-11$ ). Aggradation of approximately $175,100 \mathrm{yd}^{3}$ (219,800 tons) of sediment occurred in this third of the reach. Aggradation was indicated at all 10 cross sections in this third of the reach. The aggradation amounted to at least 10 percent of the 1980 channel volume in 3 of the 10 cross-section segments in this third of the reach.

The upstream end of the Six-Mile Pool Reach begins at the mouth of the Iroquois River, and the Iroquois River contributes a large sediment load to the Kankakee River. The suspended sediment and bed materials in the Iroquois River are composed of primarily fine particles (silt and clay). Particles of this size are transported with less stream energy than sand-sized particles. A possible reason for the aggradation of sediment in the middle third of the Six-Mile Pool is that the fine-sized sediment from the Iroquois River remains in suspension at reduced stream velocities and requires a longer time to settle out of the water column onto the streambed. This deposition might not occur in the upstream third of the reach. The ISWS analyzed the size of bed materials in the Kankakee River from the Illinois-Indiana State line to the dam in Kankakee and found a substantial increase in the amount of fine-sized particles downstream from the mouth of the Iroquois River (Bhowmik and others, 1980). This increase was found primarily in the downstream one-half of the SixMile Pool.

Aggradation and scour occurred in the downstream third of the Six-Mile Pool reach from 1980 to 1994 with a net scour of approximately $7,100 \mathrm{yd}^{3}$ $(8,910$ tons $)$ of sediment. The cross-section measurements indicated aggradation in three of the eight crosssection segments. This aggradation amounted to approximately $24,900 \mathrm{yd}^{3}$ (31,300 tons) of sediment. Scour was indicated in five of the cross-section 
segments and amounted to approximately $32,000 \mathrm{yd}^{3}$ (40,200 tons). Aggradation greater than 10 percent of the 1980 channel volume occurred in two cross-section segments and scour greater than 10 percent of the 1980 channel volume occurred in one cross-section segment.

In summary, the comparison of cross-section geometry from 1980 to 1994 indicated an overall aggradation of sediment in the Six-Mile Pool. The majority of the aggradation occurred in the middle third of the reach with most of the scour occurring in the downstream third of the reach.

\section{Period from 1978 to 1980}

From 1978 to 1980 , approximately $115,700 \mathrm{yd}^{3}$ $(145,300$ tons) of sediment aggraded in the Six-Mile Pool reach (fig. 10). Aggradation of approximately $186,000 \mathrm{yd}^{3}$ (233,500 tons) of sediment was indicated in 19 cross-section segments, and scour of approximately $70,300 \mathrm{yd}^{3}(88,300$ tons) of sediment was indicated in 10 cross-section segments.

Aggradation was predominant in the upstream third of the Six-Mile Pool reach with accumulation of approximately $93,800 \mathrm{yd}^{3}$ (117,800 tons) of sediment in 9 of the 11 cross-section segments. Scour of approximately $4,500 \mathrm{yd}^{3}$ (5,600 tons) of sediment was indicated in two cross-section segments. The overall change in this third of the reach was aggradation of approximately $89,300 \mathrm{yd}^{3}$ (112,100 tons) of sediment. The change in volume from 1978 to 1980 was at least 10 percent of the 1980 volume in two of the crosssection segments (both aggradation).

Aggradation also was predominant in the middle third of the Six-Mile Pool reach. Aggradation of approximately $88,100 \mathrm{yd}^{3}$ (110,600 tons) of sediment was indicated in 8 of the 10 cross-section segments in the middle third. Scour of approximately $3,000 \mathrm{yd}^{3}$ (3,770 tons) of sediment occurred in only 2 of the 10 cross-section segments in this third of the reach. The net change in volume for this third of the Six-Mile Pool reach was aggradation of approximately $85,100 \mathrm{yd}^{3}$ (106,800 tons) of sediment. There were no cross-section segments in which the change in channel volume from 1978 to 1980 was greater than or equal to 10 percent of the 1980 volume.

Scour was the predominant process in the downstream third of the Six-Mile Pool reach from 1978 to 1980 and from 1980 to 1994 . In this third, the net scour was approximately $58,700 \mathrm{yd}^{3}$ ( 73,700 tons) of sediment. Aggradation of approximately $4,100 \mathrm{yd}^{3}$ $(5,100$ tons) of sediment occurred in two of the eight

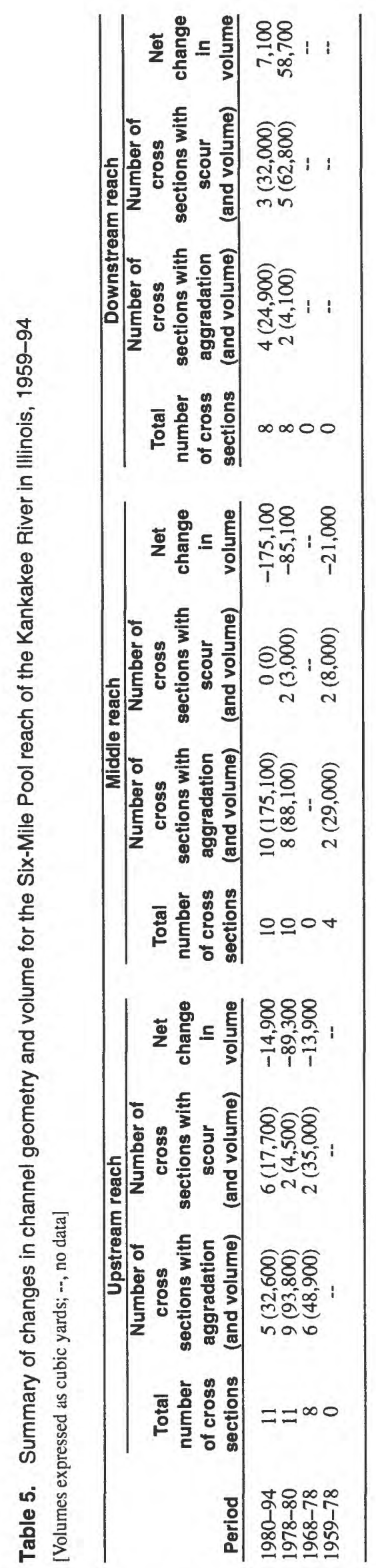

Changes in Cross-Section Geometry and Channel Volume 


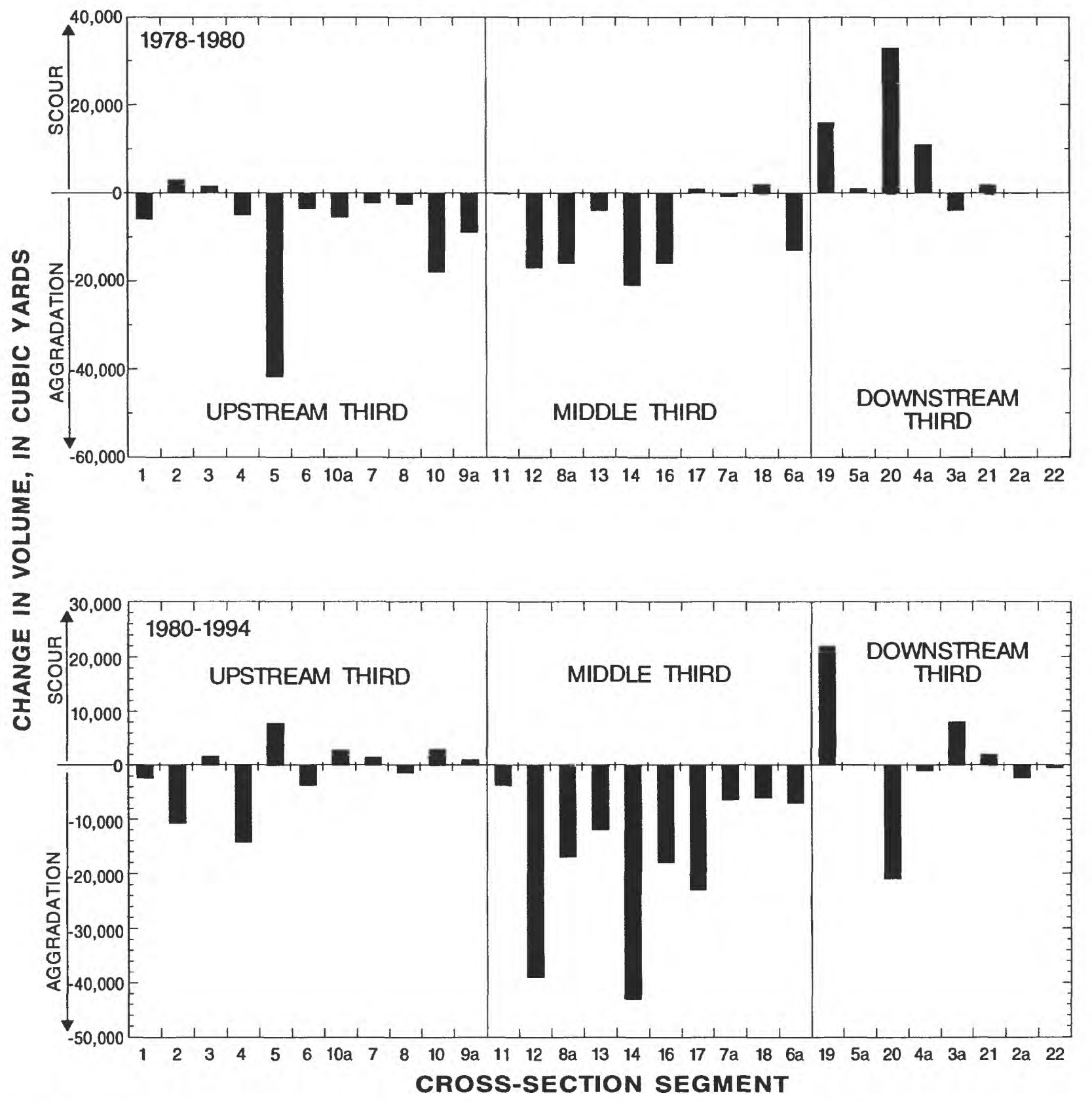

Figure 10. Changes in channel volume of the 29 cross-section segments in the Six-Mile Pool reach of the Kankakee River in Illinois, 1980-94 and 1978-80.

cross-section segments in this third and scour of approximately $62,800 \mathrm{yd}^{3}$ (78,800 tons) of sediment occurred in five of the cross-section segments. There was no change in volume in cross section 22 . The quantity of sediment scoured from the channel was greater than or equal to 10 percent of the 1980 volume in two of the cross-section segments.
The overall change from the $1978-80$ analyses for the Six-Mile Pool was similar to the results from the 1980-94 analyses; a net aggradation of sediment. Aggradation was predominant in the middle third of the Six-Mile Pool reach during both time periods. Scour was predominant in the downstream third during both periods. Aggradation occurred in almost all 
cross-section segments in the upstream third from 1978 to 1980 and in about one-half of the cross-section segments from 1980 to 1994.

\section{Period from 1968 to 1978}

Only nine cross sections were measured in 1968 (cross sections 1, 2, 3, 4, 5, 6, 7, 8, and 10). Cross section 6 was measured in 1968, but was not included in the report by the ISWS (Bhowmik and Bogner, 1981). The reason for the exclusion of cross section 6 in the ISWS report is not known, but the cross section also was not used in this analysis on the assumption that there was a problem with the 1968 data. All of the cross sections measured in 1968 were located in the upstream third of the Six-Mile Pool reach. From 1968 to 1978 , a net aggradation of approximately $13,900 \mathrm{yd}^{3}$ $(17,400$ tons) of sediment was determined for these cross-section segments (table 3 and fig. 11). Aggradation of approximately $48,900 \mathrm{yd}^{3}$ (61,400 tons) of sediment occurred in six of the cross-section segments, and scour of approximately $35,000 \mathrm{yd}^{3}$ (43,900 tons) of sediment occurred in two cross-section segments. Variable sedimentation rates were indicated for this third of the Six-Mile Pool. The measurements at these cross sections indicated a net aggradation from 1968 to 1978 , 1978 to 1980 , and 1980 to 1994 . The net change in channel volume from 1968 to 1994 in the eight crosssection segments originally measured in 1968 was a decrease of approximately $100,100 \mathrm{yd}^{3}$ (125,700 tons) of sediment.

\section{Period from 1959 to 1978}

Only five cross sections were measured in 1959. These five cross sections (cross sections 14, 15, 16, 17 , and 18) were located in the downstream half of the middle third of the Six-Mile Pool reach. No measurements were made at these cross sections in 1968. In addition, no measurement was made in 1994 at cross section 15. From 1959 to 1978 , a net aggradation of approximately $21,000 \mathrm{yd}^{3}$ (26,400 tons) of sediment was indicated in the four cross-section segments measured in all years, although aggradation occurred in only two of the segments (fig. 12). Aggradation also occurred in two segments from 1978 to 1980 , which resulted in a net aggradation of $34,000 \mathrm{yd}^{3}$ (42,700 tons) of sediment. Aggradation occurred in all four segments from 1980 to 1994 , which resulted in a net aggradation of $90,000 \mathrm{yd}^{3}$ (113,000 tons) of sediment. From 1959 to 1994 , the net change in volume in the four cross-section segments was aggradation of approximately $145,000 \mathrm{yd}^{3}$ (182,000 tons) of sediment.

The Iroquois River supplies much of the sediment delivered to the Six-Mile Pool. The sediments from the Iroquois River typically are fine-grained material that are apparently settling out and accumulating in the middle third of the reach. The islands that are present in the upstream third of the Six-Mile Pool might have formed during an earlier period of aggradation, now followed by adjustment of the channel and aggradation of sediment downstream. Aggradation in the upstream third of the Six-Mile Pool reach has occurred primarily on the sides of the channel, which resulted in the narrowing of the channel. This process generally is indicative of channel recovery (adjusting to compensate for some disturbance). Aggradation in the middle third of the reach occurs primarily on the streambed, which resulted in the shallowing of the channel.

The changes identified in the Momence Wetlands and Six-Mile Pool reaches show that aggradation can occur downstream from the mouth of a natural tributary and downstream from a manmade disturbance such as channelization. The aggradation in the Momence Wetlands reach from 1980-94 averaged approximately $3.7\left[\left(\mathrm{yd}^{3} / \mathrm{mi}^{2}\right) / \mathrm{yr}\right]\left(4.65\left[\left(\mathrm{ton} / \mathrm{mi}^{2}\right) / \mathrm{yr}\right]\right)$, and the aggradation in the Six-Mile Pool reach averaged approximately $3.0\left[\left(\mathrm{yd}^{3} / \mathrm{mi}^{2}\right) / \mathrm{yr}\right]$ $\left(3.77\left[\left(\mathrm{ton} / \mathrm{mi}^{2}\right) / \mathrm{yr}\right]\right)$ for the same period. The amount of suspended sediment transported in the Kankakee River that is accumulating in each reach and the portion of the sediment accumulating in the Six-Mile Pool that is from the Iroquois and Kankakee Rivers is not presently known. Data collected at the suspended-sediment monitoring stations will provide some information to answer these questions. The results of the cross-section geometry measurements in the Six-Mile Pool indicate that there might be substantial variability in aggradation and scour attributed to natural processes. This natural variability needs to be considered when assessing the changes in channel morphology and relating them to upstream disturbances.

\section{SUMMARY}

This study documents the adjustments of the Kankakee River, a low-gradient river typical of many rivers in the Midwest, to disturbances such as land-use changes and channelization in the drainage area. The 


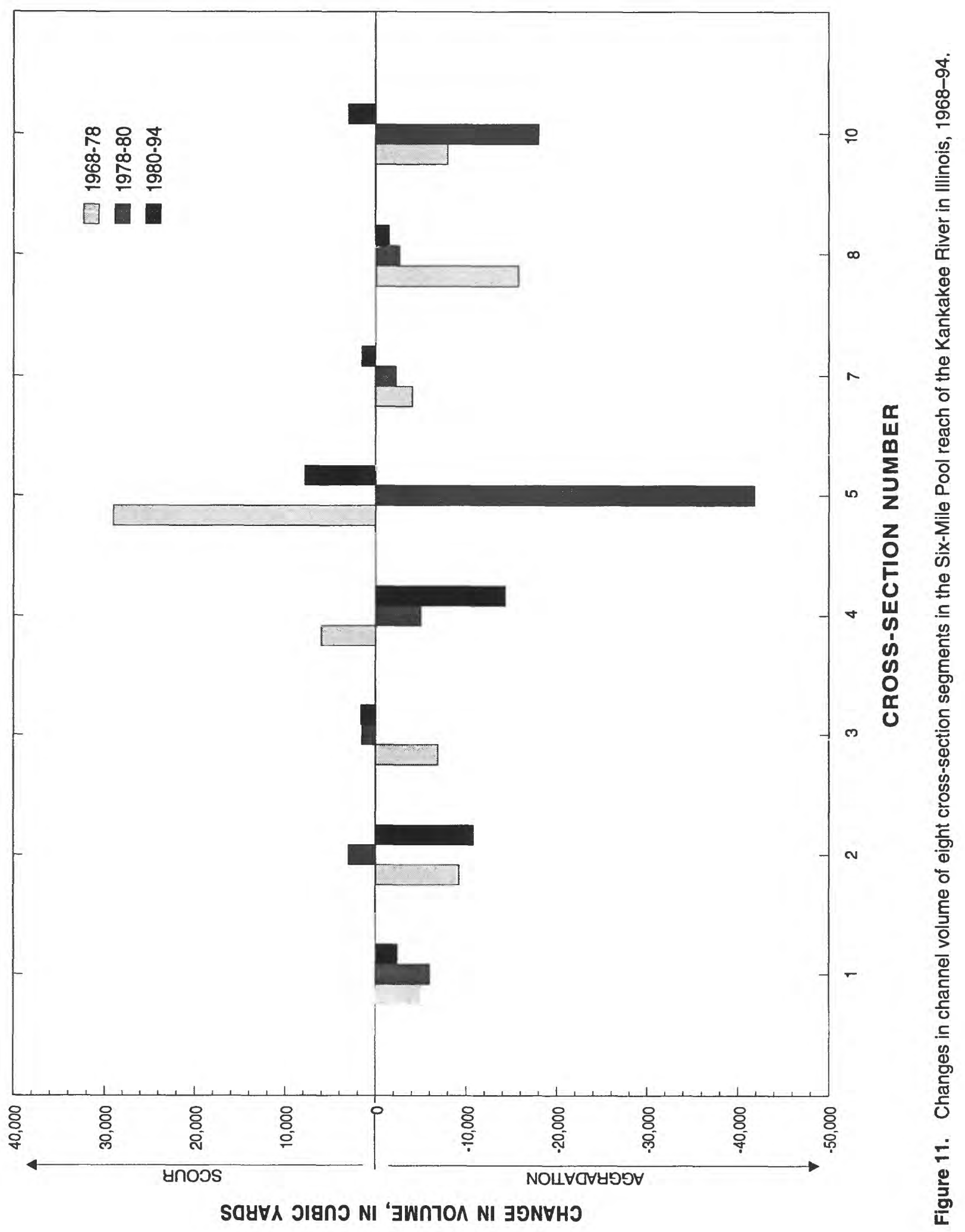




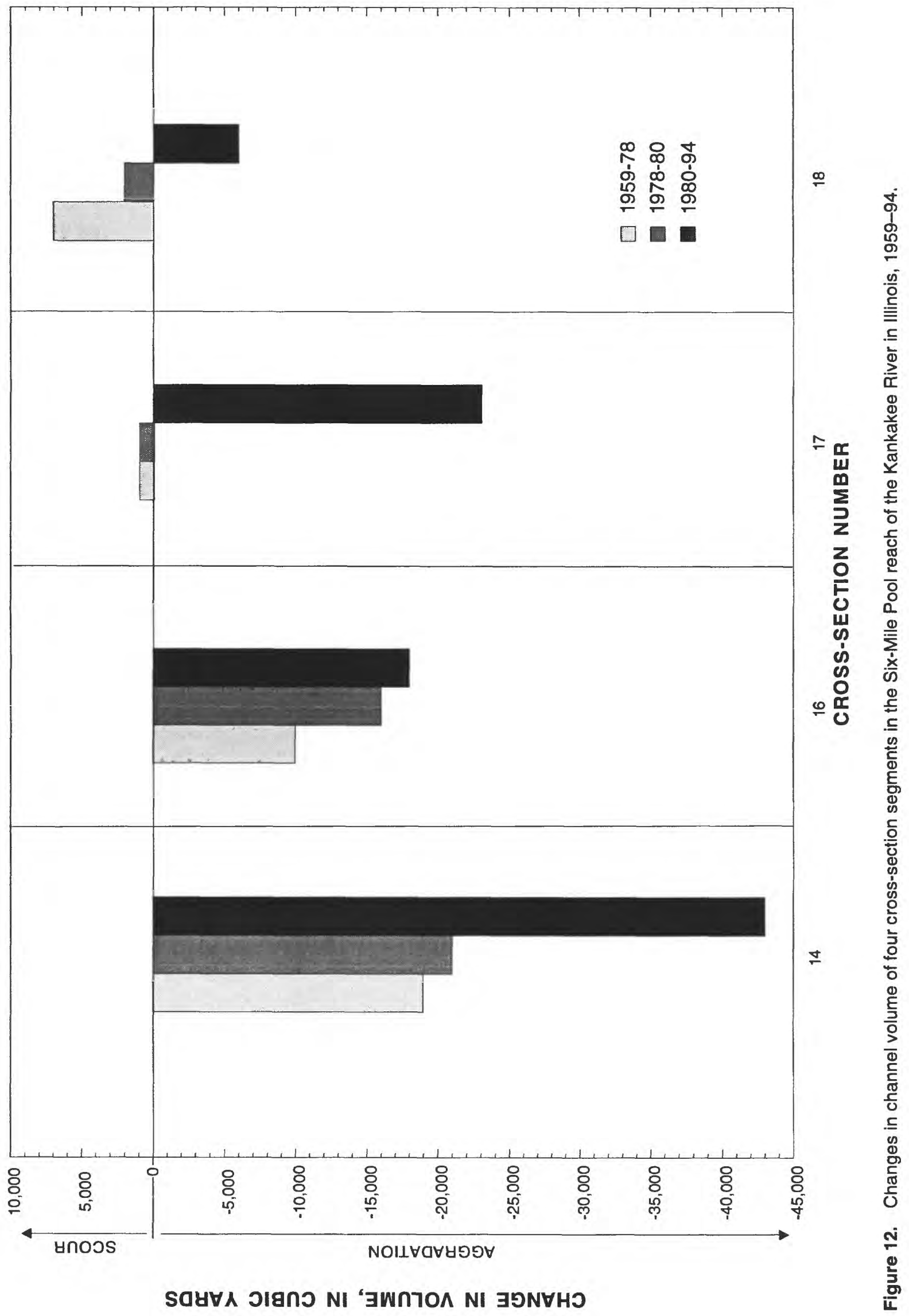


timing, magnitude, and processes of adjustment are of interest in developing better understanding of how disturbances are conveyed through alluvial stream systems in agricultural areas and how such stream systems adjust to these disturbances.

Two distinct reaches of the Kankakee River channel in Illinois were used in an analysis to determine changes in cross-section geometry and channel volume from 1959 to 1994 . The first reach extended from the Illinois-Indiana State line downstream to the mouth of Singleton Ditch near Momence, Ill. In this reach, known as the Momence Wetlands, the river channel meanders approximately $6.4 \mathrm{mi}$ through a largely undisturbed forested area. The second reach of the river used for this study was a pooled reach extending from the dam in Kankakee, Ill., upstream to the mouth of the Iroquois River. This reach generally is referred to as the Six-Mile Pool, although it is actually about 4.3-mi long.

In the Momence Wetlands, the Illinois State Water Survey (ISWS) made cross-section measurements at 36 locations in 1980, and the U.S. Geological Survey (USGS) made measurements at the same locations in 1994. In the Six-Mile Pool, cross-section measurements were made by the Illinois Department of Natural Resources, Office of Water Resources in 1959, 1968, and 1978; by the ISWS in 1980; and by the USGS in 1994. Only 4 cross sections were measured in 1959 and, subsequently, only 10 cross sections were measured in 1968 and in subsequent years.

Changes in cross-section geometry and channel volume were determined by comparing historical and recent (1994) cross-section measurements. Differences in cross-section area between time periods were determined and multiplied by the length of the river channel represented by any particular cross section to derive estimates of changes in channel volume. The Momence Wetlands reach and the Six-Mile Pool reach were divided into thirds to facilitate the analysis, based on apparent sedimentation characteristics.

In the Momence Wetlands reach, an overall aggradation of approximately $133,600 \mathrm{yd}^{3}$ (167,700 tons) of sediment occurred from 1980 to 1994. This net aggradation was the result of the aggradation of about $159,300 \mathrm{yd}^{3}$ (200,000 tons) of sediment in 25 cross-section segments and scour of about $25,700 \mathrm{yd}^{3}$ (32,300 tons) of sediment in 10 cross-section segments. Most of the aggradation occurred in the upstream third of the Momence Wetlands reach with aggradation and scour occurring in the middle and downstream thirds. The magnitude of changes was least in the downstream third of the reach.

A net aggradation of sediment in the Six-Mile Pool from 1980 to 1994 also was determined. Approximately $182,900 \mathrm{yd}^{3}$ (229,600 tons) of sediment accumulated in the reach during this period. This net aggradation resulted from the accumulation of about $232,600 \mathrm{yd}^{3}$ (292,000 tons) of sediment and the scour of about $49,700 \mathrm{yd}^{3}$ (62,400 tons) of sediment. Most of the aggradation in the Six-Mile Pool reach occurred in the middle third of the reach, whereas all 10 cross sections indicated aggradation. Aggradation and scour occurred in the upstream and downstream thirds, but scour was predominant in each of these thirds of the reach.

From 1978 to 1980 , a net aggradation of sediment was determined for the Six-Mile Pool reach. Aggradation of approximately $115,700 \mathrm{yd}^{3}$ (145,300 tons) of sediment occurred in the reach during these 2 years. This net aggradation resulted from aggradation of approximately $186,000 \mathrm{yd}^{3}$ (233,500 tons) of sediment and from scour of about $70,300 \mathrm{yd}^{3}$ (88,300 tons) of sediment. Aggradation was predominant in the upstream and middle thirds of the reach, whereas scour was predominant in the downstream third.

Eight cross sections were measured in the SixMile Pool reach in 1968. These cross sections were located in the upstream third of the reach. From 1968 to 1978 , a net aggradation of sediment in the Six-Mile Pool reach amounting to approximately $13,900 \mathrm{yd}^{3}$ $(17,400$ tons) in these 10 cross-section segments. The measurements at these cross sections indicated aggradation from 1968 to 1978,1978 to 1980 , and 1980 to 1994. A net aggradation of approximately $100,100 \mathrm{yd}^{3}$ (125,700 tons) of sediment was determined in the nine cross-section segments from 1968 to 1994.

Only five cross sections were measured in 1959 , and only four of these were measured in 1994. These cross sections were located in the middle third of the Six-Mile Pool reach. From 1959 to 1978, a net aggradation of approximately $21,000 \mathrm{yd}^{3}$ (26,400 tons) of sediment was determined in the four cross-section segments. A net aggradation of sediment was determined in the four segments from 1978 to 1980 and from 1980 to 1994 . From 1959 to 1994 , the net change in volume in the four cross-section segments was an aggradation of approximately $145,000 \mathrm{yd}^{3}(182,000$ tons) of sediment. 


\section{REFERENCES CITED}

Bhowmik, N.G., and Bogner, W.C., 1981, Sediment transport and hydraulics of flow in the Kankakee River, Illinois - Phase II: Illinois State Water Survey Contract Report 282,67 p.

Bhowmik, N.G., Bonini, A.P., Bogner, W.C., and Byrne, W.C., 1980, Hydraulics of flow and sediment transport in the Kankakee River in Illinois: Illinois State Water Survey, Report of Investigation 98, 181 p.

Gross, D.L., and Berg, R.C., 1981, Geology of the Kankakee River system in Kankakee County, Illinois: Illinois Institute of Natural Resources, State Geological Survey Division, Environmental Geology Notes 92, 80 p.

Houde, M.J., and Klasey, John, 1968, Of the people, a history of Kankakee County: Chicago, Ill., The General Printing Company, $436 \mathrm{p}$.

Ivens, J.L., Bhowmik, N.G., Brighan, A.R., and Gross, D.L., 1981, The Kankakee River yesterday and today: Illinois State Water Survey Miscellaneous Publication 60, 24 p. Jacobson, R.B., 1995, Spatial controls on pattern of land-use induced stream disturbance at the drainage-basin scale-An example from gravel-bed streams of the
Ozark Plateaus, Missouri: American Geophysical Union Geophysical Monograph, p. 219-239.

Lane, E.W. and Koelzer, V.A., 1953, Density of sediments deposited in reservoirs, Report no. 9 of a study of methods used in measurement and analysis of sediment loads in streams: St. Paul, Minn., U.S. Army Corps of Engineers, St. Paul Engineering District.

Meade, R. H., 1985, Wavelike movement of bedload sediment, East Fork River, Wyoming: Environmental Geology and Water Sciences, v. 7, no. 4, p. 215-255.

SEG Engineers and Consultants, Inc., 1989, Kankakee River master plan: A guide for flood control and land use alternatives in Indiana: Highland, Ind., prepared for the Kankakee River Basin Commission, 79 p.

U.S. House of Representatives, 1916, Kankakee River, Illinois and Indiana: Letter from the Secretary of War, U.S. Congress, 64th, 1st session, Document 931. 1931, Kankakee River, Illinois and Indiana: Letter from the Secretary of War, U.S. Congress, 71st, 3rd session, Document 784.

Vanoni, V.A., Editor, 1975, Sedimentation engineering: American Society of Civil Engineers, New York, 745 p. 


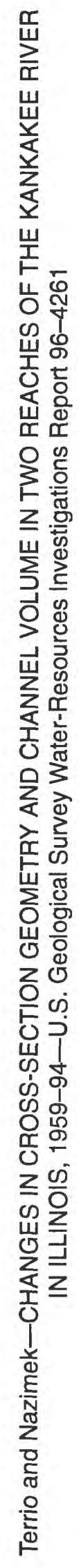

